\title{
Changing State Behaviour: \\ Damages before the European Court of Human Rights
}

\author{
Dr Veronika Fikfak, Cambridge University ${ }^{1}$
}

\begin{abstract}
Regardless of the efforts undertaken through the many reforms of the European Convention system, non-compliance with the judgments of the European Court of Human Rights remains a major problem for the Council of Europe. This article asks how we can change state behaviour and what role, if any, could damages play in this context. First, the article focuses on how the choice of remedy affects compliance and why aggravated or punitive damages look like an ideal option to nudge states into compliance. I explore recent arguments by scholars and judges who argue that the European Court of Human Rights should actively shift its approach (or perhaps already has) to nudge state behaviour towards compliance and prevention of future violations. Based on my empirical research, I show that the current case law presents several obstacles to the introduction of such damages. Building on the economic analysis of the law and insights from behavioural sciences, I reveal how the Court's approach fails to comply with any(!) of the elements needed to incentivize states to change their behaviour. I finally question to what extent aggravated or punitive damages can be efficient within a system that relies on voluntary compliance.
\end{abstract}

\footnotetext{
${ }^{1}$ Senior Lecturer in Law, Cambridge University, Homerton College. This article is part of a larger project on Damages for Human Rights Violations. I am grateful to the ESRC Future Research Leaders grant (ES/N000927/1), the Isaac Newton Trust, and the Cambridge Humanities Research Grant for helping fund the work on this project. Thanks are also due to my research associates, Sabrina Boudra and Jaka Kukavica, who coded the cases and Mandeep Dhami, who helped with statistical analysis. I have received invaluable feedback on previous drafts of the paper from participants of a number of workshops, including Joseph H. Weiler, Anne Orford, Dino Kritsiotis, Dominic McGoldrick and many other participants of the 2017 NYU/Melbourne/Nottingham International Junior Faculty Forum. Finally, immense thanks go to all the former and current ECtHR judges who spoke to me, as well as members of the Registry and Committee of Ministers. Their thorough and candid answers clarified many results of the statistical analysis and often pointed me in new (and fascinating!) directions.
} 


\section{Changing State Behaviour}

In March 2018, the Council of Europe published the news that out of all judgments rendered by the European Court of Human Rights since its inception 60 years ago, more than half - nearly 7,500 judgments - still remained unenforced. ${ }^{2}$ Regardless of the efforts undertaken through the many reforms of the Convention system and through the expansion of the Convention to 47 European jurisdictions, non-compliance with the Court's judgments remains a major problem for the COE. For years, states' failure to implement the Court's judgments has threatened to undermine the Strasbourg system and simultaneously erode the credibility of the Court. When states fail to implement the Court's judgments, this generates new, repetitive claims before the Court. Specifically, the 'failure to implement effective general measures results in the recurrence of similar infringements, producing repetitive applications and distracting the Court from its essential function.' ${ }^{3}$ These repetitive cases represent a considerable part of the Court's backlog. In fact, year-on-year, the number of judgments pending examination before the Committee of Ministers, the body responsible for supervising the implementation of Strasbourg judgments, has been steadily increasing. ${ }^{4}$ In parallel, the deficit between the number of applications introduced and applications disposed of by the Court continues to grow to the extent that victims wait for years before their claims are heard and decisions rendered. ${ }^{5}$ Although several attempts have sought to reform the institutional structures and introduce procedures to manage the growing backlog of cases more efficiently, the situation is still such as to raise concerns as to the viability of the current system and its long-term effectiveness. ${ }^{6}$

In seeking to address the problem, the emphasis has been on thinking creatively about the choice of remedies that the Court could impose on states and which would motivate states to address their human rights violations at home. Social scientists and economists have observed that human behaviour can be changed through three mechanisms of social influence: material inducement, persuasion and acculturation. ${ }^{7}$ Material inducement seeks to influence the behaviour of actors by the imposition of material costs or benefits. The imposition of a fine will motivate the state to conduct a cost-benefit analysis as to whether a certain behaviour is economically sound. If the costs of continuous behaviour outweigh the benefits, then the expectation is that the state would cease the costly actions. Whilst material inducement focuses on the 'price' of a specific behaviour, the second mechanism - persuasion - relies on persuading states of the validity or the appropriateness of a specific norm, belief or practice. Persuasion occurs when actors - in our case states - assess the content of a particular rule or practice and 'change their mind'. In the language of Harold Koh's, states obey international

\footnotetext{
${ }^{2}$ Council of Europe, Supervision of the Execution of judgments and Decisions of the European Court of Human Rights 2017: $11^{\text {th }}$ Annual Report of the Committee of Ministers, March 2018, 7.

3 A Drzemcczewski, J Gaughan, 'Implementing Strasbourg Court Judgments: the Parliamentary Dimension', in W Benedek, W Karl and A mihr (eds), European Yearbook on Human Rights 2010, vol II (Antwerp, European Academic Press, 2010), 234.

${ }^{4}$ For Statistics: Committee of Ministers, Supervision of the execution of judgments of the European Court of human Rights, Annual Reports (2008) Table 1.b Appendix 1: Statistical data, April 2009, 33.

${ }^{5}$ Council of Europe, 'High Level Conference on the Future of the European Court of Human Rights: Brighton Declaration', April 2012, para 16. See also: Council of Europe, 'High-level Conference on the "Implementation of the European Convention on Human Rights, our shared responsibility", 27 March 2015; Council of Europe, 'Copenhagen Declaration', April 2018, para 44.

${ }^{6}$ Council of Europe, 'Draft Copenhagen Declaration', 5 February 2018, para 43. Council of Europe, 'High Level Conference on the Future of the European Court of Human Rights: Interlaken Declaration', 19 February 2010 , para 8; Brighton Declaration (n 6), para 5.

${ }^{7}$ Ryan Goodman and Derek Jinks, Socializing States: Promoting Human Rights Through International Law, Oxford University Press, 2013.
} 
rules because they have 'internalized' these norms into their domestic law and practice. ${ }^{8}$ In this regard, the aim of persuasion is not merely to generate compliance but to 'internalize the new interpretation of the international norm into the other party's internal normative system.' 9 Finally, acculturation, is the process by which actors adopt the beliefs and behavioural patterns of the surrounding culture. Instead of assessing the content or the costs and benefits of international norms, acculturation relies on the cognitive and social pressures that create a compliance pull. Behavioural economists argue that such cognitive and social pressures 'induce change because actors are motivated to minimize cognitive discomfort or social costs and to achieve cognitive comfort' ${ }^{10}$ In practice, this means that states may be compelled to act in a manner compliant with international norms because such behaviour is part of membership of a specific group to which states wish to belong. As a consequence, they wish to mirror the behaviour of other states and thus remain part of an 'in-group' with a shared identity.

Like other international institutions, the current remedy framework used by the ECtHR and by the Committee of Ministers appears to rely on the use of all three tools to motivate the state to redress its actions and deter similar future violations. The ECtHR gives a clear emphasis on just satisfaction, whereby states have to compensate the victim's loss and suffering. This is sometimes complemented with non-monetary remedies. When the Court is seeking to achieve restitution in integrum and return the applicant to the position before the violation, it may order the release of a victim being held in arbitrary detention or it may go as far as requiring a state to change its legislation to prevent future actions. These remedies are imposed by the Court so infrequently that in general, the Court rather remains silent and relies on the persuasive power of its ruling. ${ }^{11}$ The expectation is that the judgment identifies the underlying problem so clearly that states are able to undertake the necessary actions to prevent future breaches at home. In the final step, the Committee of Ministers' attempts to adjust state behaviour through acculturation by publicly condemning and shaming states. ${ }^{12}$ The Committee of Ministers, for example, calls on states to abide by the Court's judgments, condemns their failure to do so and issues interim resolutions requiring their action. Together both the Court and the Committee of Ministers are supposed to provide an efficient and persuasive remedial framework, providing for different incentives for states to comply with European human rights judgments.

Given the poor compliance record of some states and the general $50 \%$ failure to execute ECtHR judgments, it is evident that the current structure and functioning of remedies is not working. The exercise of shaming states into compliance is a function for the Committee of Ministers rather than the Court and has been only varyingly successful. In a first global statistical analysis of the issue, Hafner-Burton found that whilst governments exposed and shamed as human rights violators often improve protections for political rights after being publicly criticized (e.g. they hold elections), they rarely cease or decrease their policies of torture and disappearances. ${ }^{13}$ Paradoxically, sometimes, international pressure and disapproval is followed by more repression in the short term, prompting leaders and despots to use more strategies of terror. In a sense, it may be easier for some governments to reform their legal or political structures (e.g. by organising elections or passing legislation to better protect some political rights), than to stop agents of terror that are out of their direct control. Another reason, however,

\footnotetext{
${ }^{8}$ Koh specifically focuses on courts and other domestic organs as transnational legal actors giving effect to international law at home. Harold Hongju Koh, 'Why do Nations Obey International Law?', 1997 (106) Yale Law Journal, 2599; Harold Hongju Koh, ‘Transnational Legal Process’, (1996) 75 Nebraska Law Review 181.

${ }^{9}$ Koh 1997 (n 9): 2646.

${ }^{10}$ Goodman and Jinks 2013 (n 8): 22.

${ }^{11}$ Goodman and Jinks 2013 (n 8): 24.

${ }^{12}$ Goodman and Jinks 2013 (n 8): 27-8.

${ }^{13}$ Emilie M. Hafner-Burton, 'Sticks and Stones: Naming and Shaming the Human Rights Enforcement Problem', (2008) 62 International Organization 689.
} 
is that some governments abuse human rights strategically. When faced with global pressures for reform, some governments offset the improvements they make in response to international pressure with terror, such as killings or beatings so as to boost their legitimacy at home.

Similarly, non-monetary remedies have proven to be only partially successful. In the Inter-American Court of Human Rights, for example, Hawkins and Jacobs have shown that out of 908 discrete actions that the Court has imposed, states have complied with 251 of these (i.e. $28 \%$ compliance rate). The rate of compliance decreased the more invasive the remedy was: when states had to issue an apology for their behaviour, the compliance rate was 31 percent; when states were told to punish perpetrators or restore rights to those who had them taken away, compliance had dropped to between 13 and 19\%; and finally, when the Court ordered a state to amend, repeal or adopt domestic laws or judgments, this was done in only $5 \%$ of cases. All these scarcely compare to compliance with the payment of moral and material damages (47 and 42\%). Although no similar study has been undertaken for the ECtHR, which issues non-monetary remedies much more reluctantly than the Inter-American Court, ${ }^{14}$ judges themselves insist that the Court faces the same issue with compliance as its Inter-American counterpart. ${ }^{15}$ In fact, in the most recent conference of state parties, the issue of repetitive cases arising from the nonexecution of pilot judgments imposing such non-monetary remedies was explicitly raised as a problem. ${ }^{16}$

In the end, it is to material inducement that experts seem to turn. ${ }^{17}$ Article 41 of the Convention on 'just satisfaction' as the Court's go-to remedy represents an opportunity for the Court to provide a material incentive to states to change their behaviour. As the least burdensome and most complied with remedy, it offers the greatest potential for maximising deterrence and thus ensuring remedy efficiency. In this context, scholars argue that a damage award can go beyond the aim of seeking to compensate the claimant for the harm done to them. The imposition of a high fine would motivate the state to conduct a cost-benefit analysis as to whether a certain behaviour is economically sound. If the costs of continuous behaviour outweighed the benefits, then the expectation is that the state would cease the costly actions. Aggravated damages could incentivize states to cease their recalcitrant behaviour and act to redress repeat violations and structural problems at home. ${ }^{18}$

Whilst international law has always made use of the material inducement approach to change state practices (e.g. Security Council sanctions or World Bank loans conditional on compliance),${ }^{19}$ the idea of punitive damages has generally been rejected. Neither compensation nor satisfaction are intended 'to punish the responsible State, nor ... have an expressive or

\footnotetext{
${ }^{14}$ In his article, the current Vice President of the Court speaks of about 268 cases in which general measures were awarded. A. Sicilianos 'The involvement of the European Court of Human Rights in the Implementation of its Judgments: Recent Developments under Article 46 ECHR', (2014) 32/3 Netherlands Quarterly of Human Rights 235.

${ }^{15}$ Interviews with Judges 8 and 10 of ECtHR, February 2018.

${ }^{16}$ Draft Copenhagen Declaration 2018 (n 6): para 50.

${ }^{17}$ Dinah Shelton, Remedies in International Human Rights Law, Oxford University Press, 2015, 402 ff; Paulo Pinto de Albuquerque and Anna van Aaken, 'Punitive Damages in Strasbourg' in Anne van Aaken/Iulia Motoc (eds.), The ECHR and General International Law, Oxford University Press 2017; S. Wittish 'Awe of the Gods and Fear of the Priests: Punitive Damages and the Law of State Responsibility' 1998 (3) Austrian Review of International and European Law 101-157.

${ }^{18}$ On effectiveness of punitive damages in international law: Anne van Aaken, 'Making International Human Rights Protection More Effective: A Rational-Choice Approach to the Effectiveness of Ius Standi Provisions' in Stefan Voigt, Max Albert and Dieter Schmidtchen (eds), International Conflict Resolution, Conferences on New Political Economy 23 (Siebeck/Mohr 2006): pp. 29-58.

${ }^{19}$ Goodman and Jinks 2013 (n 8): 125.
} 
exemplary character' ${ }^{20}$ In fact, even when a serious breach of an international obligation has occurred, 'the award of punitive damages is not recognized in international law.' Even more, after the International Law Commission made a proposal for 'damages reflecting the gravity of the breach', the overwhelmingly negative reaction led the Rapporteur to conclude that 'the idea of punitive damages under international law is currently unsustainable'. ${ }^{21}$ The ECtHR explicitly accepts this approach ${ }^{22}$ and has until now not considered it appropriate to accept claims for damages with labels such as 'punitive', 'aggravated' or 'exemplary'. ${ }^{23}$ Yet, as Judge De Albuquerque and Van Aaken note, the rejection of punitive damages does not mean that the Court may not in practice already be punishing states for certain types of behaviour. ${ }^{24}$ In Cyprus v Turkey, the same judge argued in his concurring opinion that the Court has 'awarded punitive damages to the claimant State' ${ }^{25}$ and in Guiso-Gallisay v Italy, the Court more generally stated that Article 41 awards must be 'a serious and effective means of dissuasion with regard to the repetition of unlawful conduct of the same type, without however assuming a punitive function. ${ }^{26}$ The Committee of Ministers has also explicitly supported the use of punitive damages to ensure the effectiveness of ECtHR judgments, as has the Parliamentary Assembly of the Council of Europe, which welcomed the introduction of fines to be imposed on states that persistently fail to execute the judgments of the Court, with a view to introducing more effective measures in the face of non-compliance. ${ }^{27}$

The proposals for the Court to adopt a more assertive approach to damages and adopt punitive damages are increasingly vocal, even within the Court. ${ }^{28}$ With the new mechanisms introduced by Protocol 14, which now permit the Committee of Ministers to bring a member state before the Court for noncompliance with a previous judgement, the argument is that such infringement proceedings now offer an opportunity for the Court to mirror the approach of EU courts. In EU law, deterrence is clearly incorporated into the primary law of the Treaty on the Functioning of the European Union, ${ }^{29}$ which provides for imposing financial sanctions on Member States for non-compliance with the judgments of the EU Court of Justice or the failure to transpose Directives. Although no similar (explicit) legal basis exists in Protocol 14, the Court's extensive discretion within Article 41 (or Article 46) would permit it to impose damages as a financial incentive on recalcitrant states to nudge them into compliance. ${ }^{30} \mathrm{With}$ the first infringement case coming to the Court, the opportunity to adopt such an approach is here and now. ${ }^{31}$

\footnotetext{
${ }^{20}$ International Law Commission, 'Draft Articles on Responsibility of States for Internationally Wrongful Acts', Yearbook of the International Law Commission, vol. II, Part Two, 2001: 99.

${ }^{21}$ James Crawford, State Responsibility: The General Part (Cambridge Studies in International and Comparative Law), Cambridge University Press 2013: 526.

${ }^{22}$ Council of Europe, European Court of Human Rights, Rules of the Court, 16 April 2018, 61.

${ }^{23}$ Akdivar v Turkey, App no 21893/93 (ECtHR, 16 September 1996); Selçuk and Asker v Turkey, App no $30451 / 96$ (ECtHR, 25 September 2001).

${ }^{24}$ De Albuquerque, Van Aaken 2017 (n 19).

${ }^{25}$ Cyprus v Turkey, App no 25781/94, (ECtHR, Grand Chamber (Just Satisfaction) 12 May 2014).

${ }^{26}$ Guiso-Gallisay v Italy, App no 58858/00 (ECtHR, Grand Chamber (Just Satisfaction) 22 December 2009), para 85.

${ }^{27}$ Council of Europe (Parliamentary Assembly), Execution of Judgments of the European Court of Human Rights, Doc .8808, 2000, para 94 .

${ }^{28}$ In fact, a review of the Court's approach to just satisfaction is currently underway. Interviews with ECtHR Judges February and March 2018.

${ }^{29}$ Consolidated Version of the Treaty on the Functioning of the European Union art. 260 (2) and (3), 2008 O.J. C 115/47.

${ }^{30}$ Some also rely on article 46 ECHR.

${ }^{31}$ Committee of Ministers, Execution of the Judgment of the European Court of Human Rights Ilgar Mammadov Against Azerbaijan, Interim Resolution CM/ResDH(2017)429 (Dec. 5, 2017)
} 
In this article, I show how the choice of remedy affects compliance and why aggravated or punitive damages look like an ideal option to nudge states into compliance. Then I turn to the most recent proposals arguing for the introduction of aggravated or punitive damages. Based on my empirical research, ${ }^{32}$ I show that the current case law presents several obstacles to the introduction of such damages. Building on the economic analysis of the law and insights from behavioural sciences, I show how the Court's approach fails to comply with any(!) of the elements needed to incentivize states to change their behaviour. I finally question to what extent aggravated or punitive damages can be efficient within a system that relies on voluntary compliance.

\section{The Current Compliance Problem and its Link to Remedies}

Traditionally, scholars insist that compliance with human rights decisions depends on the type of state and on the participation of citizens in NGOs. In this context, democratic states with an active civil society appear to be more likely to comply with human rights norms than autocratic regimes with weak civil society. ${ }^{33}$ Others insist that reputational concerns and social conformity explain patterns of compliance. Governments appear to commit and comply with legal obligations if other countries in the region do so as well. ${ }^{34}$ In the European context, for example, Falkner and Treib speak of Denmark, Finland, and Sweden as adopting a 'culture of compliance', whilst contrasting other geographic areas where compliance with decisions is weighed against domestic political cost of doing $\mathrm{so}^{35}$ and post-communist jurisdictions where law is treated as a 'dead letter'. ${ }^{36}$ Still other scholars argue that compliance is closely linked to the overall legal infrastructure capacity and government effectiveness. If the institutional capacity of the country is high (i.e. if there are several domestic bodies to check for compliance), this helps willing politicians implement judgments quickly and the adverse judgments are unlikely to be obstructed or ignored, even when the government, political elites, or other actors are reluctant' ${ }^{37}$ In this context, for example, the UK Joint Committee for Human Rights has been hailed as a key institution, holding a 'powerful and central place in the UK's parliamentary system of government', ${ }^{38}$ and acting as 'a conduit between the executive, legislature and judiciary on human rights concerns' to expedite compliance with the ECHR by 'facilitating the involvement of civil society groups and the media in monitoring compliance and holding the state to account'. ${ }^{39}$

Yet, as empirical studies have shown, compliance may not only be affected by variables related to the state but also by the type of remedies adopted by the Court in its judgments. Whilst low capacity countries may appear to take longer to implement, this may not be

\footnotetext{
${ }^{32}$ Results of this research will be published in late 2018.

${ }^{33}$ Eric Neumayer, 'Do International Human Rights Treaties Improve Respect for Human Rights?', 49(6) The Journal of Conflict Resolution, 925, 2005; Basak Cali and Alice Wyss, 'Why do Democracies Comply with Human Rights Judgments? A Comparative Analysis of the UK, Ireland and Germany', 2009, accessible on SSRN; Beth Ann Simmons and Allison Danner, 'Credible Commitments and the International Criminal Court, 64(2) International Organization, 225, 2010.

${ }^{34}$ Beth Ann Simmons, Mobilizing for Human Rights International Law in Domestic Politics, Cambridge University Press, 2009.

${ }^{35}$ Austria, Germany, Belgium, the Netherlands, Spain and the United Kingdom.

${ }^{36}$ Gerda Falkner, Oliver Treib, Compliance in the Enlarged European Union: Living Rights or Dead Letters?, Routledge, 2008.

${ }^{37}$ Dia Anagnostou and Alina Mungiu-Pippidi, 'Domestic Implementation of Human Rights Judgments in Europe: Legal Infrastructure and Government Effectiveness Matter', 25(1) European Journal of International Law, 2014 : 205.

38 ibid 222.

${ }^{39}$ C. Hillebrecht, 'Implementing International Human Rights Law at Home: Domestic Politics and the European Court of Human Rights', 13 Human Rights Review (2012) 279, 293.
} 
necessarily because they have less expertise or capacity but because often they also apparently attract judgments that are more difficult to implement. ${ }^{40}$ In this context, Yuval Shany argues that compliance 'may be strongly influenced by the substantive positions endorsed by the judgment in question and the specific type of remedies issued.' ${ }^{41} \mathrm{He}$ hypothesizes that the less objectionable the substantive portion of the court judgment is (for the losing party), and the less onerous the remedies issued, the greater the judgment's 'compliance pull' is expected to be. ${ }^{42}$ Therefore, the more the state agrees with the substance of the judgment and the less effort is required of it to enforce the decision, the more likely the compliance. This basic insight on compliance is supported not only in the international legal realism literature, which often uses game theoretic models to illustrate the interplay between state interests and compliance; ${ }^{43}$ it also finds support in some initial, small-scale descriptive empirical work, which suggests that 'high-cost' judgments (i.e. judgments the compliance with which adversely affects important state interests in a significant manner) are less complied with than 'low-cost' judgments. ${ }^{44}$ Hawking and Jacoby, for example, found that in many ECtHR cases still pending before the Committee of Ministers, just satisfaction (as the low-cost element of the judgment) was paid quickly after the initial judgment was rendered, but any additional remedies - such as individual measures or general measures - were either not adopted or considerably delayed. ${ }^{45}$ In the now infamous Iigar Mammadov v Azerbaijan case, ${ }^{46}$ the ECtHR awarded 20,000 Euros in damages to the victim, a fervent critic of the government who had been arrested and detained without any evidence of having committed the offence with which he was charged. The Court concluded that the actual purpose of his detention had been to silence or punish Mr Mammadov for criticising the Government and publishing information it was trying to hide. Without any delay, Azerbaijan paid Mammadov the damages in compliance with the judgment, yet today even years after the judgment, the victim still remains in prison despite the condemnations received from the Committee of Ministers and calls for his release.

The observation that states may be distinguishing between different remedies and choosing to comply with only the less onerous parts of the judgment is important since the aim of international courts is not only to trigger action in response to the judgment in relation to the individual appearing before the Court, but also to encourage more general convergence or internalization of norms,${ }^{47}$ compelling states to make international norms part of their domestic legal system in such a manner as to make international supervision completely unnecessary. The expectation is therefore that international norms and decisions will get embedded into the

\footnotetext{
${ }^{40}$ Sharanbir Grewal and Erik Voeten, 'Are New Democracies Better Human Rights Compliers?', 69(2) International Organization, 497, 2015. 'Low capacity' is used by the authors in the article.

${ }^{41}$ Yuval Shany, 'Compliance with Decisions of International Courts as Indicative of Their Effectiveness: A GoalBased Analysis', in James Crawford and Sarah Nouwen (eds) 3 Select Proceedings of the European Society of International Law 231, 2010, 232.

${ }^{42}$ Ibid.

${ }^{43}$ Jack L. Goldsmith and Eric A. Posner, The Limits of International Law, Oxford University Press 2005: 154-155; Andrew T. Guzman, 'A Compliance Based Theory of International Law', 90(6) California Law Review, 1823, 2002: 1846; Louis Henkin, International Law: Politics and Values, Springer, 1995: 50; George W. Downs, David M. Rocke and Peter N. Barsoom, 'Is the Good News about Cooperation?', 50(3) International Organization, 379, 1996: 379, 380-383.

${ }^{44}$ Darren Hawkins and Wade Jacoby, 'Partial Compliance: A Comparison of the European and Inter-American American Courts for Human Rights', (2010) 6(1) Journal of International Law and International Relations, 35.

45 ibid. 55ff. Similar state same behaviour was recorded in relation to judgments of the Inter-American Court of Human Rights, where the Court's awards of damages or instructions to states to apologize enjoyed greater compliance ( $42 \%$ and $31 \%$ respectively), whilst the requirement to punish perpetrators or amend, repeal or adopt domestic laws to internalize the judgment were met with the smallest compliance ( 2 instances only, ie $4 \%$ compliance). This amounts to $4 \%$ in comparison to the $42 \%$ in which compensation is paid.

46 Iigar Mammadov v Azerbaijan, App no 15172/13 (ECtHR, 22 May 2014).

${ }^{47}$ Koh (n 9); Goodman and Jinks 2013 (n 8).
} 
domestic laws and will change domestic practices to an extent that prevents violations from occurring and deters potential violators. ${ }^{48}$ In this context, however, an international court like the ECtHR together with the Committee of Ministers seeking to effectuate a change in laws and practices of its member states faces a dilemma. As the picture below shows, ' $[\mathrm{t}] \mathrm{he}$ less onerous the remedies issued by the international court are, the smaller is the potential change in state practice brought about by these remedies and thus the ... more "shallow" is the court's impact' ${ }^{49}$ Although compliance with monetary remedies may therefore be high, the impact of a judgment in the state's domestic legal system could be minimal. In fact, 'judicial remedies may fail to impact state practice either because they are rejected by states as utopian completely divorced from their interests, or apologetic - reflective of practices existing independently of the judgment - and therefore meaningless' ${ }^{50}$

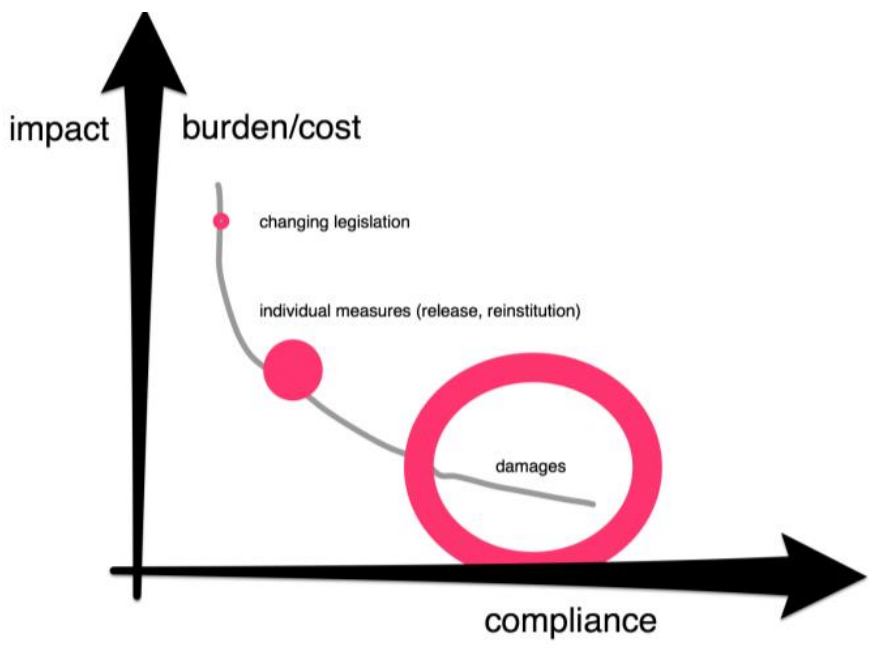

Picture 1: The efficiency diagram

Choosing a remedy requires the Court to reflect upon its institutional responsibility and limits of its competence. An essential part of that role appears to involve an assessment of which measure will be most efficient. ${ }^{51}$ In this regard, it has to strategically weigh which remedy is most likely to be implemented and which will have the deepest impact. The Court's preference for damages is clearly visible from Picture 1, where the size of the circle indicates the number of cases in which compensation $v$ other non-monetary remedies was awarded. The Court is, of course, aware of the dangers of imposing specific non-monetary remedies that no state complies with. ${ }^{52}$ On occasion, the judgments of the ECtHR contain some recommendations about the individual or general measures that ought to be adopted to fully enforce the judgment in the domestic legal system. In the first pilot judgment issued by the Court, Broniowski v Poland, the Court suggested 'appropriate legal and administrative measures' be taken to address 'malfunctioning Polish legislation' in relation to expropriation. ${ }^{53}$

${ }^{48}$ Laurence Helfer, 'Redesigning the European Court of Human Rights: Embeddedness as a Deep Structural Principle of the European Human Rights Regime', European Journal of International Law, 19(1), 2008.

${ }^{49}$ Shany (n 43): 232.

${ }^{50}$ Shany (n 43): 232; Martti Koskenniemi, From Apology to Utopia: The Structure of International Legal Argument, Cambridge University Press, 2005.

${ }^{51}$ In the interviews, judges admit that compliance is a necessary concern when choosing remedies. Judge 7 , February 2018.

${ }^{52}$ Link between compliance and reputation: G. Parameswaran 'Reputation, Compliance, and Judicial Decision Making' at https://www.law.berkeley.edu/files/LET_2014_9.pdf; Nuno Garoupa \& Tom Ginsburg, "Reputation, Information and the Organization of the Judiciary" (2009) 4 Journal of Comparative Law 228.

${ }^{53}$ Broniowski v Poland App no 31443/96 (ECtHR, 22 June 2004); Sicilianos (n 16). 
However, for the most part the Court insists that it is not its task to determine what nonmonetary remedies would appropriately satisfy the obligations under the Convention. ${ }^{54}$ The Court is concerned about over-reaching: on one side, specifying non-monetary remedies might interfere with the state's domestic legal system (e.g. '[i]t is not for the Court to prescribe specific procedures for domestic courts to follow'), ${ }^{55}$ and on the other side, choosing the means by which the state should discharge its obligation under the Convention is to be determined mutually by the state and the Committee of Ministers. ${ }^{56}$ Yet, the Committee of Ministers rather than instructing governments on measures to be taken, equally waits for the state to present its own Action Plan in which it sets out the strategy for compliance and internalization. 'Discretion therefore prevails even as innovation in legal rules and judicial practice have prompted the Court to partly diverge from it' ${ }^{57}$ The current set up therefore provides states ample freedom to determine for themselves what the remedy should be. Once an adverse ruling is rendered, states must work backwards from the violation to understand what must be changed to remedy it in the specific case and to ensure future cases do not arise.

Leaving such extensive discretion to states to determine their own remedies relies on the persuasive power of the Court's ruling. ${ }^{58}$ International courts typically have very low enforcement authority and compliance with their decisions is always voluntary. In this regard, as Shany argues, it is the substance of the judgments and the positions endorsed that will be motivate and persuade states to implement changes. ${ }^{59}$ For example, some scholars argue that when the ECtHR found that the opinion of an advocate general could not be regarded as neutral under Article 6, France, Belgium, Portugal, and the Netherlands were nudged into adopting extensive domestic judicial reforms in spite of the historical position of the advocate general in their respective systems. The judgments of the Court had painted a sufficiently persuasive picture of a need for a specific 'judicial design' within which the old role of advocate generals was simply no longer tenable and had to be revamped to make it consistent with the Convention. ${ }^{60}$ In this sense, leaving discretion to states on how to change the position of the advocate general motivated compliance because the legal systems were provided with sufficient 'breathing room' to come up with their own solution. ${ }^{61}$ Judicial silence and deference to state on how to enforce and internalize human rights decisions would therefore appear to open up a dialogue between the Court and State and overtime promote better compliance.

Yet, the decision of the Court not to be prescriptive as far as individual and general measures are concerned may mean also that many states take their prerogative by designing remedies that take less than full account of the Court's judgment. ${ }^{62}$ This point has long been acknowledged by Court insiders and on a number of occasions the Committee of Ministers has explicitly requested that the Court expressly stipulate the remedy. ${ }^{63}$ As Chayes and Chayes

\footnotetext{
${ }^{54}$ Scordino v Italy (no 1), app. no. 36813/97, (ECtHR, 29 March 2006 (GC).

${ }^{55}$ Fitt $v$ United Kingdom, app. no 29777/96, (ECtHR, 16 February 2000 (GC)).

${ }^{56}$ Sejdovic v Italy, app. no. 56581/00, Judgment 1 March 2006 (GC), about the role Committee of Ministers plays in helping the state choose the means by which it will discharge its obligation

57 Anagnostou and Mungiu-Pippidi (n 39) 214.

58 Goodman and Jinks 2013 (n 8).

${ }^{59}$ Shany (n 43): 232.

${ }^{60}$ David Kosar, 'Nudging Domestic Judicial Reforms from Strasbourg: How the European Court of Human Rights shapes domestic judicial design', 13(1) Utrecht Law Review, 112, 2017, 112.

${ }^{61}$ C. McCrudden, 'Human Rights Codes for Transnational Corporations: The Sullivan and MacBride Principles', in Dinah Shelton (ed.) Commitment and Compliance: The Role of Nonbinding Norms in the International Legal System 418, 2000, 418.

${ }^{62}$ Rolv Ryssdal, 'The Enforcement System Set Up Under the European Convention on Human Rights', in Mielle K. Bulterman and Martin Kuijer (eds.), Compliance with Judgments of International Courts, The Hague: Nijhoff, 1996, 50.

63 ibid., 49-58.
} 
argue, in international law 'ambiguity and indeterminacy' of legal language 'lie at the root of much of the behaviour that may seem to violate treaty requirements'. ${ }^{64}$ Extensive noncompliance may stem from imprecision in how obligations are framed. If the ECtHR does not specify actions or remedies required, it is difficult for states to comply and internalize its judgments. If its judgments are meant to persuade states and cajole them into a certain behaviour, then they are most useful 'if they sharply reduce uncertainty about the content of obligations'. ${ }^{65}$ In this context, compliance and internalization will occur only after states have engaged in an active assessment of the justification for these norms and understood their content. Precision therefore promotes compliance and internalization. To a certain extent, this has been shown in the Inter-American Court of Human Rights context, which provides a list of highly specific steps that must be undertaken as remedies to adverse judgments. This checklist often leads to only partial compliance, ${ }^{66}$ but the specificity nevertheless helps states with enforcement.

The ECtHR is increasingly 'quite concerned with states' inclination and capacity to abide by Court decisions and is now devoting significant resources to 'helping states' ${ }^{67}$ In this context, the Court has agreed in some cases to assist the respondent State by attempting to indicate the type of measures it could take in order to put an end to the systemic situation found in the case. This has occurred especially in cases where the Court wished to 'facilitate the rapid and effective suppression of a malfunction found in the national system of human rights protection', ${ }^{68}$ such as reinstating a judge to the Supreme Court, ${ }^{69}$ reducing a prisoner's sentence, ${ }^{70}$ or even putting in place a mechanism for enforcement of domestic judgments. ${ }^{71}$ These have shown varying results. Whilst judge Volkov was reinstated back to his position as Supreme Court justice on the instructions of the Court in 2015 and Scoppola's sentence was reduced ${ }^{72}$ the pilot decision relating to Ukraine's non-enforcement of thousands of domestic judgments remains unimplemented. ${ }^{73}$ In fact, by 2017 the situation in relation to Ukraine had become so frustrating that the Court admitted that its practice was 'incapable of achieving its intended purpose' and that it had come time for the Court to 'redefine ... its role'. ${ }^{74}$ Referring to the Brighton Declaration, the Court asserted that it only had a 'subsidiary' role to play in the context of execution of its judgments and that it had discharged it fully by specifying the appropriate remedy in the previous (pilot) decision. ${ }^{75}$ The Court proceeded to dismiss more than 12,000 cases against the state, insisting that when general remedial measures were ineffective, it was for the Committee of Ministers and the Execution Department together with State Parties to seek out new measures to motivate state compliance. ${ }^{76}$ Since the State could not be persuaded to address the violation domestically, the Court therefore gave up.

\footnotetext{
${ }^{64}$ Abram Chayes and Antonia Handler Chayes, The New sovereignty - Compliance with International Regulatory Agreements, Harvard University Press, 1998, 10.

${ }^{65}$ Goodman and Jinks 2013 (n 8): 114.

${ }^{66}$ Hawkins and Jacoby (n 44).

${ }^{67}$ Ibid.

${ }^{68}$ Scordino v Italy (no 1), app no. 36813/97, (ECtHR, 9 March 2006 (GC)).

${ }^{69}$ Volkov v Ukraine, App no 21722/11 (ECtHR, 9 January 2013).

${ }^{70}$ Scoppola v Italy no. 2 App no 10249/03 (ECtHR, 17 September 2009).

${ }^{71}$ Yuriy Nikolayevich Ivanov v. Ukraine, App no 40450/04 (ECtHR, 15 October 2009).

72 Scoppola v Italy (no 2), App no 126/05 (ECtHR, 17 September 2009).

${ }^{73}$ Ivanov v Ukraine (n 76).

${ }^{74}$ Burmych and others v Ukraine, App No 46852/13 (ECtHR, 12 October 2017 (GC)), para 182.

75 Ibid, para 194.

76 Ibid., citing Brighton declaration and Brussels declaration to underline the Court's subsidiary nature in the supervision of the execution of judgments, para 193.
} 


\section{When Monetary Remedies Can Provide an Incentive}

As shown above, non-monetary remedies - individual and general - often remain unenforced and the ECtHR generally avoids imposing these remedies out of respect for states' discretion in the implementation of its judgments ${ }^{77}$ or due to concerns about non-compliance. ${ }^{78}$ Instead, the Court's focus is on Article 41 - just satisfaction. The ECtHR awards damages ('just satisfaction') for violation of rights contained in the Convention. Regardless of the type of the violations, damages are the primary, go-to remedy used by the ECtHR. The Court insists that 'the awarding of sums of money to applicants by way of just satisfaction is not one of the Court's main duties but is incidental to its task of ensuring the observance by States of their obligations under the Convention. ${ }^{79}$ In this context, the Court 'does not provide a mechanism for compensation in a manner comparable to domestic court systems' ${ }^{80}$ Instead, the aim of awarding compensation is to 'provide reparation solely for damage suffered by those concerned to the extent that such events constitute a consequence of the violation that cannot otherwise be remedied. ${ }^{81}$

The aim of 'just satisfaction' is to compensate the victim for their 'loss', to address the wrong done to them and to correct the injustice. ${ }^{82}$ In this context, the expectation is that the Court will adjust the amount of compensation 'to the concrete situation of each' victim ${ }^{83}$ and to their personal circumstances. ${ }^{84}$ But the current practice of the Court provides no clear principles as to when damages should be awarded and how they should be measured. Although the Convention uses the term 'just satisfaction' to refer to monetary damages, it is unclear how the Court determines what is 'just'. Already in 2001, the Law Commission - the law reform body for England and Wales - criticized the approach of the Court as arbitrary and lacking in transparency. ${ }^{85}$ Instead of adopting a clear approach, the amount of the award is determined on a case-by-case basis, 'often without considering or distinguishing cases involving similar facts'. ${ }^{86}$ Practitioners and judges complain that to this day this lack of reasoned decisions articulating principles on which a remedy is afforded makes their work difficult. ${ }^{87}$ It provides little opportunity to victims of rights violations for vindication of their interests or to governments that wish to redress such breaches.

\footnotetext{
${ }^{77}$ In certain cases, the Court argues that specifying a remedy goes beyond the role of the Court, eg 'It is not for the Court to prescribe specific procedures for domestic courts to follow', Fitt v United Kingdom (n 55); 'it is not for the Court to indicate how any new trial is to proceed and what form it is to take', Sejdovic v Italy (n 56), para 127.

${ }^{78}$ Burmych and others $v$ Ukraine (n 76).

79 Salah v The Netherlands (Application no. 8196/02) (2007) 44 E.H.R.R. 55 at [70].

${ }^{80}$ Varnava v Turkey (Application nos. 16064/90, 16065/90, 16066/90, 16068/90, 16069/90, 16070/90, 16071/90, 16072/90 and 16073/90) (2010) 50 E.H.R.R. 21 at [157]. In this case, the Court also underlines that the individual interest is subordinate to the 'setting and applying of minimum human rights standard for the legal space of the Contracting States'.

${ }^{81}$ Scozzari and Giunta v Italy (Application nos. 39221/98 and 41963/98) (2002) 35 E.H.R.R. 12 at [250].

82 Shelton (n 19); Steven Greer, The European Convention on Human Rights: Achievements, Problems and Prospects (Cambridge Studies in European Law and Policy), Cambridge University Press, 2006.

${ }^{83}$ Mironovas $v$ Lithuania App nos 40828/12, 29292/12, 69598/12, 40163/13, 66281/13, 70048/13 and 70065/13 (ECtHR, 2 May 2016).

${ }^{84}$ De Albuquerque, Van Aaken 2017 (n 19).

85 The Law Commission 2001. "Damages Under the Human Rights Act 1998 - Report", Cm 4853, SE/2000/182.

${ }^{86}$ Ibid; P. Leach, "Access to the European Court of Human Rights - From a Legal Entitlement to a Lottery", (2006) 27 HRLJ 11-25.

87 J. Beatson, S. Grosz, T. Hickman, R. Singh, S. Palmer 2008. Human Rights: Judicial Protection in the United Kingdom; London, Sweet and Maxwell.; L. Lester, D. Pannick and J. Herberg 2009. Human Rights Law and Practice; London, LexisNexis ( $3^{\text {rd }}$ edition).
} 
It is in the context of this reliance on Article 41 and the lack of transparency about what is happening that claims about a shift in approach of the Court have become more relevant. In a recent article, a current sitting judge of the Court, Pinto de Albuquerque has argued that the Court 'uses punitive damages implicitly' and advocated that it 'should' do so even more frequently in the future in order to prevent repetition of wrongful conduct by states. ${ }^{88}$ Because little is known about the Court's approach to damages, ${ }^{89}$ Pinto's argument that punitive damages are being implicitly used by the Court has to be taken seriously. Given the secrecy revolving the Court's approach to Article 41, it is entirely possible that the Court has 'covertly' adopted a punitive rather than a compensatory approach to damages. The claim is of course of even greater relevance because it is made by a judge currently sitting in the Court, someone who has an insight into the work of the institution but also the power to influence its approach. ${ }^{90}$

The argument in favour of punitive damages rather than non-monetary remedies appears appealing at first sight. Monetary remedies appear less onerous and less interventionist - they do not tell the state how to behave or what measure to adopt,${ }^{91}$ they merely say how much the breach will cost. In addition, empirical studies suggest that they are complied with more frequently, on average 2 or 3 times more often than other remedies. ${ }^{92}$ But although this holds for regular compensatory awards, it is unclear to what extent this is true of punitive damages. 'An award of punitive or exemplary damages makes the admonitory function of reparation more important and express than it would be if money judgments were limited to compensatory damages. ${ }^{93}$ When a judgment condemns wrongful conduct and accords remedies to the injured, this is 'assumed to discourage repetition of the act as well as to warn others who might be similarly inclined.' 94 In many circumstances, punitive damages 'contain elements of compensation as well as deterrence and punishment. ${ }^{95}$ Shelton, for example cites cases in which the monetary damages awarded go beyond the actual harm suffered by the plaintiff (e.g. a serious wrong that happens to cause small pecuniary loss) and would go underdeterred if damages were only measured at the level of a compensatory award.

The argument that punitive damages may be efficient in changing state behaviour stems from research undertaken in two areas: economic analysis of the law and behavioural economics. The first assumes that if states behave as rational actors, then they will pursue their goals rationally. This means that if external constraints are imposed on state behaviour, states will adjust accordingly. In this context, damages can act as an incentive for states not to engage in human rights violations. 'The threat of being held liable induces the state to incorporate the losses for the victims into their decisions on whether and how to engage in certain activities. ${ }^{96}$ The state effectively performs a cost-benefit analysis, deciding to cease its behaviour because to continue it would be too costly. Yet, this line of reasoning requires that the damages imposed are high enough for the state to internalize the required behaviour.

But the practice of attaching a 'price' to a human right violation can be problematic since it may have an unexpected, negative effect on violators. Behavioural economists who

\footnotetext{
${ }^{88}$ De Albuquerque, Van Aaken 2017 (n 19).

${ }^{89}$ Informally, judges and members of the Registry admit that they are following tables, which give them a spectrum within which compensation should be awarded. But no one is completely sure how this spectrum is calculated. Ichim, Octavian. Just Satisfaction under the European Convention on Human Rights, Cambridge University Press (2014), 2; also generally acknowledged in interviews with judges and members of Registry.

${ }^{90}$ De Albuquerque, Van Aaken 2017 (n 19).

${ }^{91}$ Consistently with the black box theory that treats the state as a unity.

92 Hawkins and Jacoby (n 44), $55 \mathrm{ff}$.

${ }^{93}$ Shelton 2015 (n 19).

94 Ibid, 402.

95 Ibid, 403.

${ }^{96}$ De Albuquerque, Van Aaken 2017 (n 19), 14.
} 
have shown that people have cognitive biases and only bounded willpower, ${ }^{97}$ note that when a 'fine' is attached to violations, rational actors may perceive this as a way of paying off their wrongdoing. In principle, a fine should reduce infractions. Empirical evidence, however, suggests that a fine 'releases the actors from concerns about social disapproval' or 'social discomfort' they may have felt in violating a norm. ${ }^{98}$ In effect, a fine changes the actors' perception of the nature of the obligation. ${ }^{99}$ In a famous experiment, Gneezy and Rustichini have shown that parents who are late to pick up their children from kindergarten feel guilty about being so. But when a fine is attached to their lateness, the guilt factor is removed and parents are increasingly likely to be even more tardy to pick up their children. The introduction of the fine "not only reduces the disapproval for being late but parents also no longer consider being late as blame-worthy.' Even more, 'the imposition of a price conveys the message that the commodity of "being late" could now be bought'. ${ }^{100}$

If we translate this into the human rights context, the action of monetising a violation can give 'potential norm violators the opportunity to free themselves from following a social norm by making them pay for the norm violation'. ${ }^{101}$ By paying for the violation, states are released from the discomfort or disapproval that their initial behaviour generates. If the same violation repeatedly leads to the same price (as legal certainty and principle of equity may require), this perception may be reinforced. In this regard, the process of assigning a price to rights leads to states being enabled to effectively buy their wrongdoing. ${ }^{102}$ In effect therefore, a state may be 'willing to violate a social norm by purchasing the prerogative to do so'. ${ }^{103}$

If damages are to act as an incentive to states to change their behaviour, they therefore have to take into account both the rational and irrational aspects of state behaviour. Whilst the economic analysis of law 'has traced the incentive effects of punitive damages on potential wrongdoers based on the assumption that they pursue their material advantage', ${ }^{104}$ behavioural economists focus on how actors react in practice. In this context, for example, Eisenberg and Engel have shown that depending on the amount of damages, actors may be deterred the more uncertain the threat of the sanction and the higher its severity if they were sanctioned in the past. ${ }^{105}$ It is not enough to impose high damages, expecting that states will undertake a straightforward cost-benefit analysis. Rather, both the uncertainty and the harshness of damages appear to be at play, as well as players' previous experiences. Behavioural economists also consider how norms are expressed. As Cooter argues, punitive rather than aggravated damages are successful because they 'allow[] judges ... to express righteous anger through speech and punishment. Expression of emotions by the court demonstrates the strength of its commitment to the law in question. Perception of this commitment shapes the expectations of

\footnotetext{
${ }^{97}$ For an overview, see Christine Jolls, Cass R. Sunstein and Richard. H. Thaler, 'A Behavioral Approach to Law and Economics' (1998) 50 Stanford Law Review 1471; Russell B. Korobkin and Thomas S. Ulen, 'Law and Behavioral Science: Removing the Rationality Assumption from Law and Economics' (2000) 88 California Law Review 1051; Cass R. Sunstein (ed), Behavioral Law and Economics (Cambridge University Press 2000); Eyal Zamir and Doron Teichman (eds), Handbook on Behavioral Economics and the Law (Oxford University Press 2014).

${ }^{98}$ Goodman and Jinks 2013 (n 8): 178, 179.

${ }^{99}$ Uri Gneezy and Aldo Rustichini, ‘A fine is a Price', (2000) 29(1) Journal of Legal Studies 1, 14.

${ }^{100}$ Ernest Fehr and Armin Falk, 'Psychological Foundations of Incentives', (2002) 46 European Economic Review 687: 709, 711 .

${ }^{101}$ Ibid., 711.

102 Margaret Jane Radin, Contested Commodities, Harvard University Press, 2001.

103 Goodman and Jinks 2013 (n 8): 179.

${ }^{104}$ De Albuquerque, Van Aaken 2017 (n 19).

105 Theodore Eisenberg and Christoph Engel, 'Assuring Civil Damages Adequately Deter: A Public Good Experiment', 11(2) Journal of Empirical Legal Studies, 301, 2014.
} 
citizens [e.g. states] and changes their behaviour.' 106 The expressive power of adjudication is therefore also crucial. ${ }^{107}$ In their judgments, courts provide clear signals to the violator state that they disapprove of its behaviour. Whilst in theory, it is argued that 'adjudicative expression can, by itself, influence the behaviour of existing disputants and of future potential disputants, ${ }^{\prime} 108$ empirical experiments show that when a fine is framed retributively (as a punishment) and publicly, it will act as a more effective deterrent. ${ }^{109}$ When the damage amounts are interpreted as a 'punishment' or 'sanction', states are less likely to transgress the rules. Because punishment is expressed publicly, the additional publicity element adds a clear message to participants and to observers about what type of behaviour is undesired or immoral. The 'threat of a more publicly extracted fine might act as a more powerful incentive for cooperative behavior.' 110

If - as some judges at the Court argue - damages should seek to incentivize states to change their behaviour and thus serve the purpose of deterrence, the question is whether the Court has already adopted this approach and whether Article 41 is currently being used as a potential deterrent. 'Whenever a purpose of a norm is stated, a need for a social analysis arises in order to verify whether the purpose will be fulfilled in reality.' 111 Joining together the lessons from economic analysis of law and behavioural economists, there are three elements that a damage award would have to fulfil to have a deterrent effect: (1) high value, (2) unpredictability, (3) and it would have to be framed retributively. Building on empirical research, the next three sections address each in turn. They reveal not only that the current ECHR practice is lacking in all three respects, but also the obstacles that may prevent the adoption of punitive damages in the future.

\section{An Economic and Behavioural Analysis of ECHR's Current Approach to Damages}

\section{A. Transparency, Elevated Value and Individualization}

From the perspective of the economic analysis of law, damages may be seen as an instrument that can provide behavioural incentives to states to change their actions. The threat of being held liable induces actors (states) to incorporate potential losses into their decision-making and to reassess how often they should engage in such activity and what measures they should take to prevent such events in the future. Taking more care, putting measures into place to prevent violations, can lower probability of future violations and thus - in the long term - significantly reduce the actors' losses. Yet, such cost-benefit analysis works only if the costs of paying-off continuing, repetitive breaches are so high that (at least in the long-term) they outweigh the costs of putting in place preventative measures. Damages should therefore 'be high enough to make taking due care [i.e. putting in place preventative measures] ... more attractive than applying a lower care level. ${ }^{112}$ In effect, the economic line of reasoning implies that damages

\footnotetext{
106 Robert Cooter, 'Punitive Damages, Social Norms and Economic Analysis', 60 Law and Contemporary Problems (1997), pp. 73-91.

${ }^{107}$ Richard McAdams, 'The Expressive power of adjudication' in Peer Zumbansen and Gralf-Peter Calliess (eds), Law, Economics and Evolutionary Theory, Edward Elgar Publishing, 2011.

108 Ibid, 1046.

109 Tim Kurz, William E. Thomas, Miguel A. Fonseca, 'A fine is a more effective financial deterrent when framed retributively and extracted publicly’, 54 Journal of Experimental Social Psychology, 170, 2014.

110 Ibid.

${ }^{111}$ De Albuquerque, Van Aaken 2017 (n 19).

${ }^{112}$ Louis Vischer, 'Economic analysis of punitive damages' in Koziol H., Wilcox V. (eds), Punitive Damages: Common Law and Civil Law Perspectives, Tort and Insurance Law book series (25), Springer Vienna, 2009.
} 
should be high enough for the violator to consider seriously whether a different, non-violative behaviour would not be more cost-effective.

The ECtHR's approach to setting damages, especially non-pecuniary damage takes a different approach. As English courts have found, compensation at the ECtHR is 'ungenerous' in comparison to English tort standards, ${ }^{113}$ and in general the amounts are exceedingly low and often merely 'symbolic'. ${ }^{114}$ Even in the most serious cases, the awards tend to be modest, e.g. 20,000 Euros for torture, about 50,000 for disappearance of a loved one. ${ }^{115}$ The graphs below contain all of the non-pecuniary awards made in the last 13 years for violations of Article 3 (torture, inhuman and degrading treatment) and Article 5 (arbitrary detention). ${ }^{116}$ They clearly show that the amounts of damages are low: 74.5 percent of all Article 3 applicants are awarded compensation below 10,000 Euros, and in $94.8 \%$ of victims, the amount is below 20,000. In Article 5, 80.7\% of victims receive below 5000 and $94.8 \%$ below 10,000.
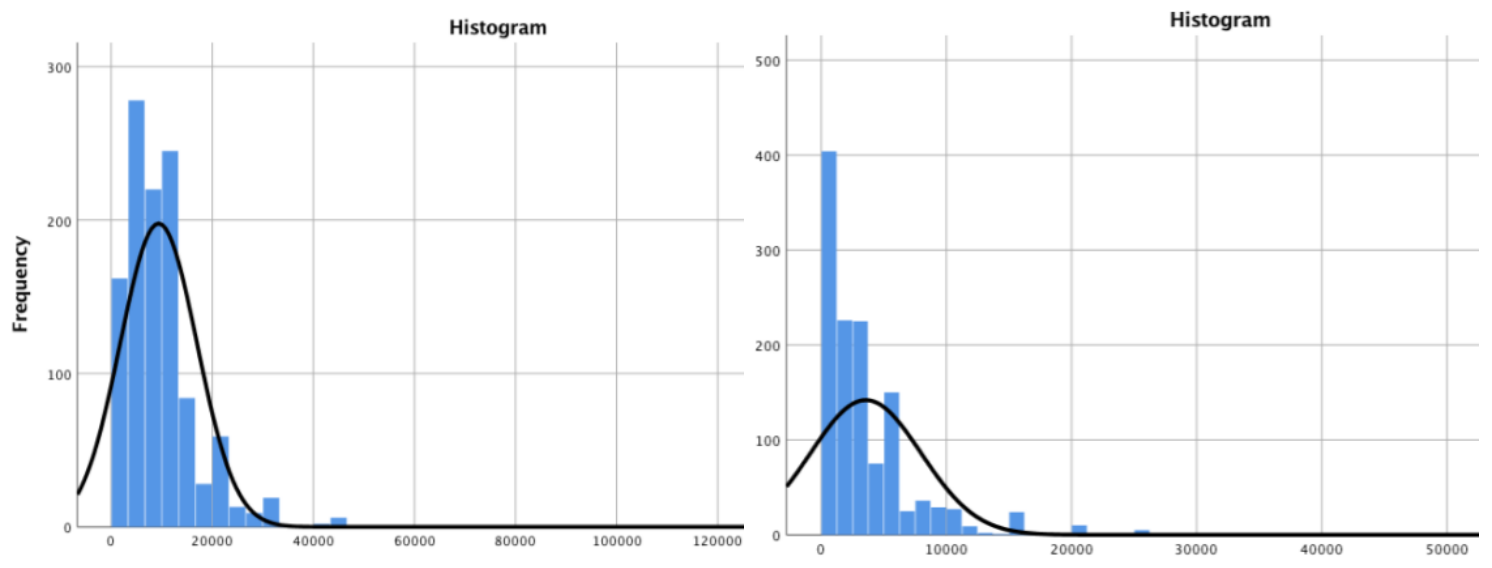

Picture 2: Just satisfaction for torture, inhuman and degrading treatment and detention

These considerably 'ungenerous' amounts are problematic from two perspectives. In the context of determining the appropriate amount, economists underline that a court needs to take into account the probability that a violator will be held liable. Victims of human rights violations face numerous obstacles before they get to the ECtHR. They have to exhaust all domestic remedies; if their case is declared admissible, they have to show that it was the state who committed the violation through active or passive behaviour; ${ }^{117}$ after which they have to wait numerous years before their case is heard and before the judgment is rendered, all without certainty that their case will be successful. ${ }^{118}$ Victims may find it too expensive to bring a suit and pursue the violator through the different stages of the process, especially when comparing the costs to the expected outcome of the process. They may thus suffer from what is known as 'rational apathy'. ${ }^{119}$ At the same time, the violating state may choose to offer settlement money to the victim in order to prevent the case from coming to the Court or afterward, to prevent the

\footnotetext{
${ }^{113}$ Watkins v SOSHD [2006] 2 AC 395, [64].

${ }^{114}$ Lorse v Netherlands App no 52750/99 (ECtHR, 4 February 2003).

115 J Beatson, Human Rights: Judicial Protection in the United Kingdom, Sweet and Maxwell, 2008, [7-103]. J. Varuhas. Damages for Breaches of Human Rights; Oxford, Hart Publishing, 2015, 237; Faulkner v Secretary of State for Justice [2013] UKSC 23, [27].

116 Altogether more than 1500 victims are examined. See author's article on results of empirical research.

${ }^{117}$ Philip Leach, Taking a Case to the European Court of Human Rights, Oxford University Press, 2017.

118 Out of 85,951 decisions made in 2017, 70,356 were struck out or declared inadmissible and only 15,595 were decided on the merits (18\% of all decisions made). Annual Report of the European Court of Human Rights (20162017) 163, at https://www.echr.coe.int/Documents/Annual_report_2017_ENG.pdf.

${ }^{119}$ Vischer 2009 (n 112).
} 
final judgment from being rendered. ${ }^{120}$ All of these elements contribute to the fact, that a finding of violation before any court, including the ECtHR, is uncertain. The violator takes this into account and may be willing to 'gamble' that due to any of these obstacles the finding of a violation is unlikely. High damages can ameliorate this situation. ${ }^{121}$ They may provide 'an incentive to victims who have suffered severe dignitary harm' to pursue wrongdoers regardless of how difficult the path may be. ${ }^{122}$ The more uncertain the outcome, the higher the damages have to be if the victim is to be sufficiently motivated and potential wrongdoers dissuaded from emulating wrongful conduct. 'The factor with which compensatory damages should be multiplied, is reciprocal of the probability of being held liable.' ${ }^{123}$ Therefore, if the probability of a finding of a violation is $50 \%$, then damages 'have to be doubled to provide the correct incentives'. ${ }^{124}$

But the low-level awards made by the Court do not take into account the tough route the applicant faces in getting to a violation. This allows states to be more willing to risk being taken to the Court, especially when there is a specific social benefit (or utility) to breaching the Convention. The case of Ilgar Mammadov can serve as an example. An opposition politician in Azerbaijan, who was considered a likely candidate for the presidential elections of Azerbaijan in 2013, was arrested, put on trial and sentenced in a move 'widely seen as politically motivated'. ${ }^{125}$ Although the ECtHR had found a violation of Articles 5, 6, and 18 of the Convention and awarded 20,000 Euros in compensation, which was promptly paid, Mammadov remains in prison. The just satisfaction award - which, it should be noted was set at the very high end for Article 5 violations, ${ }^{126}$ therefore had no deterrent effect and the imprisonment of Mammadov clearly has greater utility to Azerbaijan than the damages awarded. Economists argue, therefore that damages 'should be so high that they deter even the [violator] who [enjoys] these unaccepted benefits.' 127

The 'ungenerous' amounts awarded are problematic also from the perspective of how they assess the victim's suffering. A part of using damages as a deterrent requires also that the Court estimates properly how much the victim has suffered. 'If there is a risk that compensatory damages fall short of the true losses of the victim, the [violator] does not receive adequate behavioural incentives.' ${ }^{128}$ In order to motivate the violator to change their behaviour, the awards therefore have to focus on the victim and the loss or harm suffered. Yet, judges at the Court openly admit they struggle with assessing victim's suffering, especially in the context of non-pecuniary damages. On numerous occasions they 'acknowledge that it may generally be

\footnotetext{
${ }^{120}$ Helen Keller, Magdalena Forowicz, Lorenz Engi, Friendly Settlements before the European Court of Human Rights, Oxford University Press, 2010.

${ }^{121}$ Dorsey D. Jr. Ellis, 'Fairness and Efficiency in the Law of Punitive Damages', S.Cal.L.Rev 56 (1982) 25 and 26; Robert D. Cooter 'Punitive Damages for Deterrence: When and How Much?', Alabama Law Review 40 (1989) 1148 ff; AM Polinsky and S Shavell, 'Punitive Damages: An Economic analysis', Harvard Law Review 1998, $887 \mathrm{ff}$. For the application of punitive damages to overcome the problem of rational apathy in EU law: Commission Staff Working Paper accompanying the White Paper on Damages actions for breach of the EC antitrust rules SEC (2008) 404. Also see R. Van den Bergh, W. van Boom and M. van der Woude, 'The EC Green Paper on Damages Actions in Anti-trust Cases - An Academic Comment', (2006) 14 <ec.europa.eu/comm/competition/antitrust/actionsdamages/filesgreenpapercomments/erasmusuniversity.pdf>.

${ }^{122}$ Shelton 2015 (n 19): 402.

${ }^{123}$ Vischer 2009 (n 112): 5.

124 ibid., see also Polinsky and Shavell 1998 (n 121).

${ }^{125}$ UK Foreign office statement https://www.gov.uk/government/news/azerbaijan-foreign-office-statement-onopposition-leaders; also US Department of State statement https://photos.state.gov/libraries/azerbaijan/749085/highlights/prIsmayilliTrialOutcome.pdf.

${ }^{126}$ Falling Within the $98.9 \%$ of all Article 5 awards.

${ }^{127}$ Vischer 2009 (n 112): 9, Emphasis added; Ellis 1982 (n 121): 32; Cooter 1989 (n 121) 87; Polinsky and Shavell 1998 (n 121): 194.

${ }^{128}$ Vischer 2009 (n 112): 7
} 
questionable whether human-rights violations can be cured by money' and that it is difficult or impossible 'to express in monetary terms the pain of having lost [a] son.' ${ }^{129}$ In interviews, they acknowledge they have no expertise in this respect and argue that they find it easier to assess the harm with reference to quantifiable elements (especially duration of a violation), which allow for comparisons between cases. ${ }^{130}$ In this context, empirical results show that variables such as victim's assessment of loss, their particular circumstances or vulnerability, and distress suffered, appear to not have a bearing on the final award. ${ }^{131}$

Instead, statistical analysis has shown that it is the respondent state (and variables connected to it) that has a significant influence on the awards made by the Court. Damages appear to correlate better with the respondent state and its level of economic development. ${ }^{132}$ The Court argues that by adjusting damages to the state, it is seeking to ensure that victims have equal purchasing power, ${ }^{133}$ but the almost exclusive focus on the state uncovered in empirical studies goes beyond that. My results reveal that the state's previous infringement record also plays a role. In relation to some violations, there seems to be a reduction of compensation from case to case for the same type of behaviour. ${ }^{134}$ As other scholars have noted, in multiple applicant cases, compensation to each victim is lower than if they appeared in a single-applicant claim. ${ }^{135}$ These results would suggest that the more a state violates a certain right, the less it pays for that breach. When asked about this trend of award decreases, judges admit that the results may be due to compliance worries that they grapple with in their decisionmaking. ${ }^{136}$ When states invoke the economic crisis as affecting their ability to pay, this is taken into account in the Court's approach to cases. ${ }^{137}$ Judges also admit, for example, that Ukraine's claims about limited resources (due to a war it is fighting in the west), may have been taken into account in the imposition of lower awards made by the Court. ${ }^{138}$ In a series of cases relating to the non-enforcement of the decisions of Ukrainian courts, the compensation for individuals waiting for enforcement was decreased from initial 5000 Euros for non-pecuniary damage (in 1999) to 2500 Euros in Ivanov pilot decision (in 2008) and then to 2000 Euros in Pysarskyy (in 2013). Although initially, the Court drew careful distinctions between victims waiting for enforcement below and above three years (1500 and 3000 Euros respectively), ${ }^{139}$ gradually the distinction was removed and since 2013 the applicants were paid 2000 Euros regardless of the amount of time they waited for the enforcement of decisions, with some waiting longer than

\footnotetext{
${ }^{129}$ Nagmetov v Russia App No 35589/08 (ECtHR (Grand Chamber) 30 March 2017, concurring opinion of Judges Nussberger and Lemmens, para 5.

${ }^{130}$ Interview with Judge 3, February 2018.

${ }^{131}$ For example, there is no correlation between amount claimed and award provided. See author's forthcoming article 2018.

${ }^{132}$ Apicella v Italy App no. 64890/ 01 (ECtHR, 10 November 2004), para. 26. 47. See author's forthcoming article 2018, which reveals that the state and the state's systemic violation count provides a considerably better fit than victim variables.

${ }^{133}$ Ichim (n 89) 47.

${ }^{134}$ For example, in the context of Article 3, where we could expect a punitive approach, states pay only a few Euros more for each additional case in which a violation of Article 3 is found against them. Initial results for Article 5 are even more interesting and suggest a decrease in compensation to victim of 88 Euros per each additional case against the state. See author's forthcoming article.

${ }^{135}$ David Harris, Michael O’Boyle, Colin Warbrick, The Law Of the European Convention on Human Rights, OUP $\left(3^{\text {rd }}, 2014\right) 156$.

${ }^{136}$ Interviews with Judge 7 and 8, February 2018. See also explanation in Arvanitaki v Greece, app. no 27278/03, (ECtHR, 15 Feburary 2008 (GC)), underlying that group cases are different.

${ }^{137}$ Fr. Tulkens, "La Convention européenne des droits de l'homme et la crise économique. La question de la pauvreté" ("The European Convention on Human Rights and the economic crisis. The issue of poverty"), Journal européen des droits de l'homme / European Journal of Human Rights, 2013/1, pp. 8 et seq.

${ }^{138}$ Interview with Judge 7, also underlying that the aim is to get the victims at least 'something'.

${ }^{139}$ Kharuk and Others v. Ukraine, App No 703/05 (ECtHR [Committee] 26 July 2012).
} 
ten years. ${ }^{140}$ Even more, the awards which were initially made only for non-pecuniary damage, were now intended to cover both pecuniary and non-pecuniary damage regardless of the financial loss suffered by the applicant.

The story does not end there. In 2015, and in light of the thousands(!) of outstanding cases before the Court on non-enforcement of decisions, the Court accepted that the Ukrainian Government could avoid further claims, by paying applicants only 1000 Euros for nonpecuniary damage, together with an undertaking to enforce the domestic judgments. ${ }^{141}$ From 1999 to 2015, the 'price' for non-enforcement of domestic judicial decisions had therefore fallen from 5000 Euros to $20 \%$ of this. Even after Ukraine's promises to the victims to pay them the reduced amounts and enforce the outstanding judgments, applicants complained that their promises went unfulfilled. ${ }^{142}$ In spite of reducing the financial burden on Ukraine, the original structural problem remained unaddressed.

Such judgments speak of the concern on the part of the Court about the ability and willingness of the state to comply with its decisions. ${ }^{143}$ But from an economic analysis perspective, the approach of the Court is completely counter-intuitive since one would expect recalcitrant behaviour to get more and more expensive. Instead, the Court's approach makes violations cheaper and turns the cost-benefit analysis upside-down. Even more, from a behavioural economic viewpoint it reinforces the idea that the award is a 'price' for recalcitrant behaviour and provides little or no encouragement for states to change their behaviour. States pay for the delay but then continue their actions without making any changes. The 29,000 Ivanov-type cases, which the Court has received between 1999 to 2017 reveal how the remedies adopted by the Court have failed to incentivize Ukraine to change its behaviour. In fact, by overwhelming the Court with cases generated by unaddressed structural problems, Ukraine appears to have managed to get a 'discount on quantity' for its behaviour. This decision to adjust or effectively lower damages to facilitate states' compliance has had no deterrent effect and instead could lead to the potential collapse of the system. In 2017, in Burmych v Ukraine, when the issue of Ivanov-type cases arose again before the Court, the Grand Chamber effectively gave up on trying to incentivize Ukraine to comply with its judgments. The Court dismissed all of its remaining 12,148 Ivanov-type cases as well as any future cases ${ }^{144}$ and forwarded them to the Department of Execution at the Council of Europe. The Court's argument was that it had done everything it could, now it was for the Department of Execution to find a solution to implementation of its judgments. ${ }^{145}$

\footnotetext{
${ }^{140}$ Pysarskyy and Others v. Ukraine App No no. 20397/07 (ECtHR [Committee], 20 June 2013).

${ }^{141}$ Samoylenko and 4,999 Others v Ukraine, App Nos. 11212/08 - 2803/15, 20 January 2015, through the means of unilateral declarations; Burmych and others $v$ Ukraine (n 76): paras 40 and 41.

${ }^{142}$ Burmych and others $v$ Ukraine (n 76): para 42; dissenting opinion argues that no compensation had been paid to any of the applicants, para 9.

${ }^{143}$ This approach is of course not limited to Ukraine. Especially in pilot judgments, countries may be given a 'discount' to enable them to redress the violation at home. In this regard, the Pinto legislation in Italy, which is intended to enable victims of lengthy proceedings to claim their remedy before Italian courts, accords victims only $45 \%$ of what they would get at the ECHR level. Instead of 1500 Euros per year of delay, the awards imposed are closer to 700 Euros per year. This 'discount' allows Italy to deal with thousands of victims whilst closing off further recourse to the Strasbourg Court. Stornaiuolo c. Italia, Application No. 52980/99, (ECtHR, 8 August 2006, para 94); Delle Cave e Corrado c. Italia, App. no. 32850/02, (ECtHR, 16 July 2013). Such measures also address concerns about the Court being overburdened with repetitive cases.

${ }^{144}$ Burmych and others $v$ Ukraine (n 76): See dissenting opinion of Judges Yudkivska, Sajó, Bianku, Karakas, De Gaetano, Laffranque and Motoc on pro futuro aspect of the judgment, para 6.

145 This conclusion was challenged by very strong dissents. The approach adopted by the Court was in danger of 'transferring the determination of human rights claims from a judicial authority, as the Convention system requires, to a political body, albeit a collective one, namely the Committee of Ministers.' But more than this: it was accused of giving the violator Governments the power 'to seize control of thousands of cases brought against
} 
The first requirement of damages as a deterrent requires awards to be individualized, so that the victim's loss and suffering is recognized and that the low probability of being successful before the Court is acknowledged. Yet, the ECtHR does not focus on the victim, but on the state and its capacity to comply with the decision. As the dissenters in Burmych put it, the majority's decision to join all 12,148 applications without 'assess[ing] each of the cases individually' contradicts the idea of the Convention system as one of 'individual justice'. ${ }^{146}$ Under the Convention, each victim has the right to have their case decided after an individual judicial consideration of their single application and a thorough examination of their case file. Yet, the Court circumvents this fact. Although the approach of the Court in Burmych appears counter-intuitive from an economic analysis of the law perspective, the reduction of fines from case-to-case is perhaps not in itself surprising. Psychologists show that our reactions to large number of cases (e.g. large losses of human life, large scale atrocities or violations) are different than when we are dealing with a single case. Susskind, Maurer, Thakkar, Hamilton and Sherman find that 'a single individual, unlike a group, is viewed as a psychologically coherent unit. This leads to more extensive processing of information and stronger impressions about individuals than about groups.' ${ }^{147}$ People feel more distress and compassion when 'considering an identified single victim than when considering a group of victims.' ${ }^{148}$ There is a novelty and immediacy with one single victim. ${ }^{149}$ When 'a violation becomes a statistic (as it necessarily does when you are dealing with 29,000 similar cases on non-enforcement of domestic judgments), this leads to psychological numbing: 'repetition eventually numbs the moral imagination'. ${ }^{150}$ Charities receive less donations for two starving children rather than one and even less when the problem is introduced in statistical terms. ${ }^{151}$ People are less willing to help unidentified statistical victims than identified individuals. ${ }^{152}$ In essence, the bigger the numbers, the more our view of and consideration for each individual victim is blurred. ${ }^{153}$ When people in the cases dealt by the Court become unidentified statistical victims, then this 'leads to apathy and inaction'. ${ }^{154}$ The first problem of the Court's approach is therefore uncovered.

them before the Court and the entire philosophy of the Convention judicial supervision system [was] distorted.' Burmych and others $v$ Ukraine (n 76), Dissenting opinion of Judges Yudkivska, Sajó, Bianku, Karakas, De Gaetano, Laffranque and Motoc, Paras 13 and 19.

146 Ibid.

${ }^{147}$ Paul Slovic and David Zionits 'Can international law stop genocide when out moral intuitions fail us?' in Ryan Goodman, Derek Jinks and Andrew Woods (eds) Understanding Social Action, Promoting Human Rights (2012) $100,115$.

148 Tehila Kogut, IlanaRitov, 'The “identified victim” effect: an identified group, or just a single individual?', (2005) 18(3) Journal of Behavioral Decision Making, 157.

${ }^{149}$ See dissenting opinion of Helen Keller in Navalnyy $v$ Russia, in which she disputes the award of damages in comparison to prior similar cases: 'although Mr Navalnyy's rights were violated in the context of seven different arrests, he was awarded just twice the amount of compensation awarded to an applicant whose rights were violated on only one occasion, as shown by the example of the Frumkin case. In effect, each of Mr Navalnyy's arrests was compensated for by less than a third of the amount by way of just satisfaction that Mr Frumkin received for the violations of his rights suffered in conjunction with his arrest. While the awards made under Article 41 depend on a number of factors, and no two cases are identical in this or other regards, this is a glaring difference that accordingly demands an explanation. The question here, then, is whether it is justified to reduce the amount of compensation awarded to Mr Navalnyy for the individual violations of his rights in the light of the fact that they occurred on multiple occasions.' Navalnyy v Russia, nos. 29580/12, (ECtHR, 2 February 2017), Emphasis added. ${ }^{150}$ Richard Just, 'The Truth Will Not Set You Free: Everything We Know About Darfur, and Everything We're not Doing About it.' The New Republic, August 27, 2008, xx.

${ }^{151}$ Daniel Västfjäll, Paul Slovic, Marcus Mayorga, Ellen Peters, 'Compassion Fade: Affect and Charity Are Greatest for a Single Child in Need ', PLOS ONE 9(6), 2014.

${ }^{152}$ Kogut and Ritov 2005 (n 146); Deborah Small, George Loewenstein, 'Helping a Victim or Helping the Victim: Altruism and Identifiability', The Journal of Risk and Uncertainty, 26:1; 5-16, 2003.

${ }^{153}$ Slovic and Zionts in Goodman (n 145), 117.

154 Ibid. 


\section{B. Predictability of the amount of damages}

Behavioural economists have found that unpredictable damages have a better deterrent effect than fully predicable (or certain) damages. Looking at the issue both from a criminal law (in relation to sentencing) and tort law perspective (in relation to damages), these economists have experimented with uncertainty/certainty of sanctions and showed that a lack of predictability adds to the efficiency of legal norms. Using insights from behavioural economics and a simple experiment, Baker, Harel and Kugler found that when individuals are told with certainty what their sanction will be (or how much they will be charged for a specific breach), the deterrence effect of the primary norm was reduced. ${ }^{155}$ Over the course of the experiment the value of the sanction was varied and participants had to decide at each point whether to breach the norm or obey it. The authors found that the greater the uncertainty regarding the size of the fine, the more unlikely the participants were to breach the norm and thus trigger the sanction. The conclusions drawn from this experiment were that, at least in the context of tort law, ${ }^{156}$ such results suggest that reform efforts aimed at making non-economic and punitive damages more predictable may decrease the deterrent effect of the law. The paper, which was written at a time when tort reform was discussed in the US, ended up rejecting the proposals that one should impose an upper limit on tort damages and thus make damages more certain. Reduction in uncertainty resulting from such reform could 'well magnify the expected loss in deterrence.' 157 The conclusion was therefore that a lack of predictability seems to be a key ingredient of an efficient remedy network.

The current practice of the ECtHR in relation to the imposition of damages is secret. There appear to be no clear principles as to when damages should be awarded and how they should be measured. Yet, in determining the quantum of non-pecuniary damages, the Court has established a set of internal 'scales on equitable principles ... in order to arrive at equivalent results in similar cases. ' 158 These were developed 'after years of examining' the reasons for the delays attributable to the parties under the Italian procedural rules, leading to the violation of Article 6, length of proceedings. The scales exist mostly for 'repetitive' or 'clone' cases, or indeed for 'pilot-judgments' and remain unpublished. ${ }^{159}$ Some authors argue that this lack of transparency is due to the Court being concerned about creating more litigation, but judges themselves admit that the lack of clarity preserves their discretion in the context of Article $41 .{ }^{160}$

At first sight, therefore, damages before the ECtHR appear to be uncertain. Yet, the data of the empirical analysis reveals a completely different picture. The graphs above show clearly that there is very little variation in amounts. $74.5 \%$ of all Article 3 applicants are awarded compensation below 10,000 Euros, and in $94.8 \%$ of victims, the amount is below 20,000. In Article 5, 80.7\% of victims receive below 5000 and $94.8 \%$ below 10,000 Euros. The consistency of the Court's approach is such that out of 1128 applicants whose Article 3 rights were found to have been violated in the last 13 years, only one stands out as a clear outlier: a case of multiple occasions of torture, which exceptionally brought the victim 105,000 Euros.

155 Baker, Tom; Harel, Alon; and Kugler, Tamar, "The Virtues of Uncertainty in Law: An Experimental Approach" (2004) 89 Iowa Law Review 443.

${ }^{156}$ In criminal law such efficiency arguments arguably have to take second place to human rights concerns and principles of legality and certainty, which include the rule that sentences have to be predictable.

${ }^{157}$ Baker 2004 (n 153): 477.

${ }^{158}$ Cocchiarella v Italy (Application no. 64886/01), (ECtHR 9 March 2006), not yet reported, at [67]. This has now also been confirmed in numerous books (Ichim (n 89) 2).

159 The Right Honourable Lord Woolf, M. McKenzie, P. McMahon, Dr. C. O’Cinneide and L. Clarke, Review of

the Working Methods of the European Court of Human Rights (December 2005) <http://www.echr.coe.int/Documents/ 2005LordWoolfworkingmethodsENG.pdf> accessed 29 September 2014.

${ }^{160}$ Interview with Judge 10. 
Even if the Court enjoys discretion when it comes to the award of damages, it seems that it is choosing to exercise it in a consistent, predictable manner.

In fact, judges acknowledge that those states who appear frequently before the Court (e.g. systemic violations) may have seen the tables and might even know precisely the spectrum within which the Court is almost certainly going to set the damage amounts. ${ }^{161}$ Those who have worked at the Court speak about the need for transparency and standardization - an objective basis on which calculation of damages takes place. ${ }^{162}$ Yet, in the absence of a general overview of the case law and an internal statistical analysis, they fail to see how intuitive the damage amounts are. In fact, the approach of the Court to calculating damages is so consistent, that judges take into account years or days of imprisonment (eg under Article 5), rather than consider whether an individual was especially vulnerable. ${ }^{163}$ This need to resort to only objective, quantifiable factors in determining damages means that more often than not the frequent violators are well aware of the 'price' their violation will trigger, even if the precise manner in which the amount will be calculated remains unknown. ${ }^{164}$

What states know about the amount of damages as well as their previous experience before the Court are important, because it is not the theoretical threat of damages but states' actual (prior) individual experience with sanctioning that affects their future behaviour. ${ }^{165}$ Since the current approach of the Court provides for low and predictable damage amounts, states are enabled to plan the cost of their violations. An intriguing example of such behaviour is Russia, which is one of the worst systemic violators of the Convention (together with Turkey, Romania and Ukraine). Russian legislation explicitly requires that the annual budget of the country contains a part intended to pay off ECHR violations. ${ }^{166}$ From 2010 to 2016, the amount 'reserved' for ECHR compensation has increased from 114 million rubles (1.7 million USD) to 500 million Rubles (7.6 million USD). ${ }^{167}$ At the same time, however, little has been achieved to address the source or underlying causes of these violations (especially the conduct of domestic authorities in the context of Articles 2 and 3). Although budgeting for ECHR compensation does not necessarily mean that Russia 'plans' its violations in advance, this clearly indicates some sort of calculation as to how much ECtHR violations will cost in a given year. Russia may be aware of the cases which are coming through the pipeline of the Court, yet rather than invest money into addressing systemic problems and breaches (or providing alternative remedies at home like Italy), ${ }^{168}$ Russia instead puts money towards compensating human rights violations. It seems therefore that the predictability of the ECtHR damages

\footnotetext{
${ }^{161}$ Interview with Judge 10, February 2018; also dissent in Burmych acknowledges that the Court 'usually discusses matters of judicial policy with different stakeholders in order to find optimum acceptable solutions', (n 76). This includes states.

162 Ichim (n 89) 260.

163 Celik and Yildiz v Turkey, app. no. 51479/99, (ECtHR, 10 November 2005), concurring opinion of Judge Turmen, clarifying that each day of imprisonment in Article 5-3 cases costs 500 Euros (once the threshold of three days imprisonment is reached).

${ }^{164}$ For example, in article 6 cases, judges take as a reference point a sum of between EUR 1,000 and EUR 1,500 for each year's duration of the whole proceedings, and they increase it by EUR 2,000 when what was at stake was particularly important. Ichim (n 89) 126.

165 Theodore Eisenberg and Christoph Engel, 'Assuring Civil Damages Adequately Deter: A Public Good Experiment', (2014) 11(2) Journal of Empirical Legal Studies 301.

${ }^{166}$ Federal Law No. 359-FZ of 14 December 2015 'On the Federal Budget for 2016', Art. 21(5).

167 Note that Russia has rejected compliance with Yukos v Russia, app. No. 14902/04, (ECtHR 20 September 2011) following a decision of its Constitutional Court and 'compensation reserve' in the budget does not therefore refer to that decision. See Decision of the Russia Constitutional Court 19 January 2017, available in documents submitted to the Committee of Ministers; DH-DD(2017)207.

${ }^{168}$ As was done by Italy in relation to length of proceedings, the Pinto legislation (n 141) allowed for compensation to be awarded at home, rather than turning to the ECHR.
} 
appears to allow frequent violators to plan the cost of their violations, whilst doing little to address the underlying problems in their legal system.

The Court asserts that its awards seek to work as 'a serious and effective means of dissuasion' especially in relation to systemic and repetitive violators. ${ }^{169}$ Yet, the Russian example clearly indicates that the current approach of the Court may be allowing (or enabling) states to think of compensation as a 'price' to be paid for a violation, whilst at the same time failing to act as an incentive for states to change their behaviour. The current operation of damages under the ECHR therefore appears to have no deterrent impact on the behaviour of states.

\title{
C. Retribution and publicity as an essential element of punitive damages
}

The third element that is necessary for damages to have a deterrent effect is that they be framed retributively and publicly. In this context, experiments have shown that if the financial amount is presented as a punishment, the threat of such retributive sanction is likely to produce the desired effect on behaviour. ${ }^{170}$ In contrast, when the amounts are interpreted as performing a compensatory function (i.e. when they are labelled as compensation for loss or harm), these are likely to be seen as an opportunity to compensate the victims of violative behaviour and have been shown to be ineffectual deterrents. It is the expressive function of labelling a fine as a 'punishment' or 'sanction' that means that individuals are less likely to transgress the rules. In experiments conducted, individuals were less likely to be late when a 'punishment' attached to their behaviour.

Studies have also found greater behavioural effect of fines when these were extracted publicly (or threatened to be extracted publicly). ${ }^{171}$ The publicity element contains a clear message to participants and to observers about what type of behaviour is undesired or immoral. In experiments, when punishment was threatened to be imposed publicly, individuals showed up considerably earlier for the meeting than control groups. Thus, 'it would appear that the threat of a more publicly extracted fine might act as a more powerful incentive for cooperative behavior. ${ }^{\text {'172 }}$ It is the cumulative effect of both variables - framing the fine retributively and extracting/imposing it publicly - that has the most efficient impact on participants. ${ }^{173}$ Therefore, in addition to the high value and unpredictability of damage amounts, it is crucial that the fine is framed as a sanction and that it is administered publicly.

The ECtHR explicitly rejects the position that the damages are (or should be) punitive. The Practice Directives of March 2007 and January 2016 state that

\begin{abstract}
the purpose of the Court's award in respect of damage is to compensate the applicant for the actual harmful consequences of a violation. It is not intended to punish the Contracting Party responsible. The Court has therefore, until now, considered it inappropriate to accept claims for damages with labels such as "punitive", "aggravated" or "exemplary". ${ }^{174}$
\end{abstract}

The Practice Directives therefore clearly state that the Court has 'until now' not deviated from general international law, where punitive damages have been explicitly rejected. ${ }^{175}$ In case after

169 Guiso-Gallisay v Italy App no 58858/00 (ECtHR, 8 December 2005); see also Cyprus v Turkey (n 25), concurring opinion Judge Pinto, para 17.

${ }^{170}$ Kurz (n 109).

${ }^{171}$ Ibid.

172 ibid.

173 ibid.

174 Rules of the Court, Practice Directions, p 60 and ff, Emphasis added; https://www.echr.coe.int/Pages/home.aspx?p=basictexts/rules/practicedirections,.

${ }^{175}$ Commentary on the ILC Articles of State Responsibility, p 98 and ff; yet note that some scholars argue that ILC Articles apply only in relationships between states, but not in relationship between individual and state, in which punitive damages could be a good way of achieving deterrence. Wittish (n 19). 
case, the Court has consistently and explicitly refused claimants' requests for exemplary, aggravated or punitive damages, ${ }^{176}$ including when such requests were specifically made to 'reflect the particular character of the violations suffered by [applicants] and to serve as a deterrent in respect of violations of a similar nature by the respondent State'. ${ }^{177}$ In Varnava and others $v$ Turkey, the Court held that 'It considers there to be little, if any, scope under the Convention for directing governments to pay penalties to applicants which are unconnected with damage shown to be actually incurred in respect of past violations of the Convention...' 178

In spite of this clear and consistent rejection of punitive damages, there are increasing voices both in academia and in judicial circles that argue that the ECHR - as a lex specialis system ${ }^{179}$ - allows for the imposition of such damages since it primarily does not function as an interstate dispute resolution mechanism. ${ }^{180}$ The focus on individual claims, it is argued, allows the European Court to depart from traditional international law and shift its approach to adopt punitive damages, especially in cases of gross violations of human rights; prolonged, deliberate non-compliance with a judgment of the Court; and severe curtailment of the applicant's human rights, in particular restricting his or her access to the Court. ${ }^{181}$ In this context, some insist that a shift has already occurred and that the Court 'has already changed its course and uses punitive damages, albeit rather implicitly.' ${ }^{182}$ Judge Pinto de Albuquerque (together with Anne van Aaken) for example argues that the Practice Directive 'is no longer up to date.' ${ }^{\prime 83}$ He goes further and maps out seven ways in which the Court has implicitly applied punitive damages. ${ }^{184}$ Similarly, Dinah Shelton argues that 'there seems to be some shift towards considering exemplary and aggravated damages, if not punitive measures. ${ }^{185}$ She relies on the same arguments as provided by Pinto, as well as separate opinions made by other judges in which they expressly refer to awards in certain cases as punitive. ${ }^{186}$ The proposition is therefore that the Court has allowed aggravated, exemplary or even punitive damages. In the next sections I investigate two most-often cited examples in which it is argued such damages have been imposed implicitly.

\footnotetext{
${ }^{176}$ In chronological order: Vilenchik v Ukraine, App No 21267/14, (ECtHR, 3 October 2017); , Greens and M.T. v. the United Kingdom, nos. 60041/08 and 60054/08, § 97, ECHR 2010; Lopez Guio v Slovakia, App 10280/12, (ECtHR, 3 June 2014); Stefanou v Greece, App No 2954/07, (ECtHR, 22 April 2010); İkincisoy v. Turkey, no 26144/95, §§149, (ECtHR, 27 July 2004); B.B. v. the United Kingdom, no. 53760/00, § 36, 10 February 2004; Akdivar and Others, cited above, § 38, and Orhan v. Turkey, no. 25656/94, § 448, 18 June 2002; Lustig-Prean and Beckett v. the United Kingdom, [GC], nos. 31417/98 and 32377/96, §§ 22-23, 27 September 1999; Selçuk and Asker v. Turkey, 24 April 1998), Reports 1998-II, p. 918, § 119; Menteş and Others v. Turkey (Article 50), 24 July 1998, §§ 18-21, Reports 1998-IV; Hood v. the United Kingdom [GC], no. 27267/95, §§ 88-89, ECHR 1999-I. 177 Greens and M.T. v. the United Kingdom, ibid.

178 Varnava $v$ Turkey (n 80).

${ }^{179}$ For the most recent assertion of ECtHR as a lex specialis (in the context of just satisfaction - Article 41), see Nagmetov v Russia, app no. 35589/08, (ECtHR, 30 March 2017), para 32 (dissenting opinion); also Cyprus v Turkey (n 25) para 42.

${ }^{180}$ Shelton arguing that just satisfaction is not limited to only compensatory damages; Shelton (n 19) 402.

${ }^{181}$ Cyprus v Turkey (n 25) concurring opinion of Judge Pinto; also Pinto in Krupko and others v Russia, app. No. 26587/07, (ECtHR, 26 June 2014).

182 De Albuquerque, Van Aaken 2017 (n 19).

183 ibid.

184 This is also expressed in his concurring opinion in Cyprus v Turkey (n 25).

185 Shelton (n 19) 410.

${ }^{186}$ Gaygusuz v Austria, app.no. 17371/90, (ECtHR 16 September 1996) Judge Matscher; Ouranio Toxo and others $v$ Greece, app. no. 74989/01, (ECtHR 20 October 2005) Judges Lorenzen and Vajic; Trevalec v Belgium, app. no. 30812/07, (ECtHR 25 June 2013), Judge Pinto; Cyprus v Turkey (n 25) Judge Pinto; note also those who criticize the amounts awarded by the Court, labelling them as punitive: Khalaifia and others $v$ Italy, App. No. 16483/12 (ECtHR, 1 September 2015), dissenting opinion of Judge Lemmens.
} 


\section{Cases with no reported loss}

The first situation concerns cases in which applicants make no claim for compensation. In its Practice Directions the Court makes it explicit that the applicant 'must make a specific claim' for just satisfaction. If the applicant fails to comply with the requirement and makes no claim, the 'Court considers that there is no call to award him any sum on that account.' ${ }^{187}$ This approach is consistent with the '[t]he inherent purpose' of compensation to 'place the injured party in the position in which he or she would have been had the violation found not taken place.' When the injured party 'does not even claim to have sustained any damage', then under the compensatory model - the Court should award no damages. ${ }^{188}$ As a matter of principle ('ne ultra petitum rule'), ${ }^{189}$ therefore, victims that claim no compensation will receive no damages. In the words of the Inter-American Court 'reparations should not make the victims or their successors either richer or poorer.' 190

Yet, as scholars note, the European Court has awarded compensation in certain cases in which the applicant has not asked for compensation or in which they failed to submit the claim within the required time limits. ${ }^{191}$ The most recent of these cases was Nagmetov, in which the applicant's son had been killed by police using firearms during a protest. The Court found a double violation of Article 2 of the Convention. In particular, the Court ruled that in addition to the substantive breach of Article 2 (unlawful and excessive use of lethal force), there were numerous shortcomings in the investigation and Russia had not provided any compensation for the killing over the nine years that had passed after the events. The applicant, however, made no request under Article 41 in the prescribed time-limit and the question arose whether the Court could award the applicant any damages. Relying on previous cases in which 'the Court had exceptionally found it equitable to award compensation in respect of non-pecuniary damage, even where no such claim had been made', ${ }^{192}$ the Chamber decided to make an award. The case then travelled to the Grand Chamber, so that it could clarify the practice of the Court, given that different sections of the Court adopted different approaches in these cases. ${ }^{193}$ The Grand Chamber asserted that the Court's guiding principle was equity but that it also enjoyed 'a degree of flexibility' in respect of non-pecuniary damage. Put together these principles required it to provide 'an objective consideration of what is just, fair and reasonable', including not only the position of the applicant but the overall context in which the breach occurred. This meant that judges could exercise discretion in exceptional circumstances, where the gravity of the breach and its impact on the applicant were such that an adequate reparation was unavailable or restitution in integrum impossible. Since these elements were fulfilled in Nagmetov, it was thus appropriate for an award to be made. ${ }^{194}$

In his article, Judge Pinto de Albuquerque (together with Anne van Aaken) suggests that ' $[w]$ hen the Court awards compensation in an amount higher than the alleged damage or

\footnotetext{
${ }^{187}$ Rule 60 of the Rules of the Court; Drozd v Ukraine, app. No.12174/03, (ECtHR 30 July 2009) para 75; Pandjikidzé v. Georgia, app. No. 30323/02, (ECtHR, 27 October 2009).

${ }^{188}$ De Albuquerque, Van Aaken 2017 (n 19).

189 The amount requested is usually interpreted as imposing a ceiling on compensation amounts, eg Lorse and others (n 114).

${ }^{190}$ Case of Ituango Massacres v Colombia, (InterAMCtHR, 1 July 2006), para 348.

${ }^{191} \mathrm{P}$. Tavernier 'La contribution de la jurisprudence de la CEDH relative au droit de la responsabilite international en matiere de reparation - Une remise en cause necessaire' (2007) 72 Revue Trimestrielle de Droits de l'Homme 958; Ichim (n 89) 122-123.

${ }_{192}$ Nagmetov v Russia, app no. 35589/08, (ECtHR, 30 March 2017), para 49; Vladimir Fedorov v Russia, app no. 19223/04, (ECtHR, 30 July 2009); Nadrosov v Russia, app no. 9297/02, (ECtHR, 31 July 2008); Borodin v Russia, app. no. 41867/04, (ECtHR, 6 November 2012).

${ }_{193}^{19}$ Nagmetov v Russia, ibid, concurring opinion of Judges Nussberger and Lemmens, paras 3 and 4.

${ }^{194}$ Nagmetov $v$ Russia, ibid, main judgment, para 73.
} 
even independently of any allegation of damage, the nature of the just satisfaction is no longer compensatory, but we deem it punitive since it surpasses the amount claimed; i.e. the harm suffered by the victim. ${ }^{\prime 95}$ In her book on Remedies in Human Rights Law, Shelton appears to make the same argument. ${ }^{196}$ But looking at the decision, the award is clearly not framed retributively. The focus of the Court is squarely on the applicant and how they have been impacted by the violation: 'The non-pecuniary damage existed in the present case on account of the moral suffering and distress sustained by the applicant due to the unlawful and unjustified lethal use of firearms against his son and the incomplete investigation into the matter.' 197 In other cases, in which the Court adopts a similar approach, it also argues that 'the applicant must have suffered' 198 or that 'a mere finding of a violation' cannot 'compensate' the 'distress and frustration resulting from the procedural violation of Article 3'. ${ }^{199}$ From these statements, it is clear that the Court is trying to impute suffering to the victim, a move that appears to seek to fit within the compensatory model.

The Court does acknowledge that the 'absolute nature of the right' and 'fundamental character' of the right play a role in the award of non-pecuniary damages. ${ }^{200}$ Most of the decisions, in which the Court awards damages without a reported loss concern Articles 2 and 3 (right to life and right to be free from torture) ${ }^{201}$ In this regard, the exception appears to apply only in those circumstances where scholars would argue punitive damages are appropriate and should be awarded - gross violations of human rights. It could therefore be argued that the Court is focused on vindicating the right in question and looks to its absolute nature and fundamental character and the importance of the interest it protects (including 'human dignity'). Since the applicant did not 'set a price' on the right, it is the Court that feels compelled to do so. In this regard, the Court may be going beyond the 'compensatory' aim and affirming the importance of the violated right, but it is nevertheless far from imposing a punitive damage. If damages were punitive (or aggravated), they would seek to phrase the damages with reference to the wrongdoer, the violating state. Looking at the wording of the Court's decisions, however, it appears that the Court is not focused on the conduct of the state, or its intentional or potentially cruel conduct. There is no mention that the award may be of punitive character; and even the dissenting judges do not label the award as intending to punish the state. ${ }^{202}$ Instead, the term 'compensation' appears countless times in the Nagmetov judgment, including a reference to the Chamber's decision to exceptionally 'award compensation in respect of non-pecuniary damage'. ${ }^{203}$

\footnotetext{
195 De Albuquerque, Van Aaken 2017 (n 19), though note that Pinto makes the argument first in Cyprus v Turkey (n 25), concurring opinion of Judge Pinto, para 13.

196 Shelton (n 19) 403.

${ }^{197}$ Nagmetov v Russia, ibid, main judgment, para 83, emphasis added.

198 A.N. v Ukraine, app. no. 13837/09, (ECtHR, 29 January 2015), para 100.

${ }^{199}$ Igor Ivanov v Russia, app. No. 34000/02, (ECtHR, 7 June 2007), para 50; Fedorov (n 191); Nadrosov v Russia (n 191); Borodin v Russia (n 191).

${ }^{200}$ Chember v Russia, app no. 7188/03, (ECtHR, 3 July 2008); Kats and others v Ukraine, app no. 29971/04, (ECtHR, 18 December 2008), Mayzit v. Russia, app no. 63378/00, (ECtHR, 20 January 2005), paras 87-88.

${ }^{201}$ Including when the the applicant was unrepresented and given the circumstances it was 'exceptionally possible' (Kats, ibid.) and circumstances where 'exceptional', Mayzit v Russia (ibid). In this regard, it is important to note that cases in which the Court awards damages without a victim's request are exceedingly rare. In the dataset of all Article 3 cases decided in the last 13 years, there were only 10 such cases, out of 64 in which no claim was made; i.e. less than $1 \%$ of the whole dataset of Article 3 violations. Prior to Nagmetov, these awards appear to have been made only once a year!

${ }^{202}$ Nagmetov v Russia (n 191).

${ }^{203}$ Ibid., para 49, emphasis added. The Chamber further uses the terminology: 'The Court considers that the applicant must have suffered anguish and distress which cannot be compensated for by a mere finding of a violation.' Nagmetov v Russia, app no. 35589/08, (ECtHR, Chamber decision, 5 November 2015), para 72.
} 
Even if we accept Judge Pinto's assessment that the Court's recognition of punitive damages in this regard has been implicit, and that ' $[t]$ he fundamental purpose of that remedy [in Nagmetov] is hence to punish the wrongdoing State and prevent a repetition of the same pattern of wrongful action or omission by the respondent State and other Contracting Parties to the Convention,' ${ }^{204}$ it is clear that the current practice of the Court fails all three elements that are required to make Nagmetov type damages deterrent. The amount of the award made (50,000 Euros) is in line with other similar awards for violations of Article 2. ${ }^{205}$ It is phrased in 'compensatory' language. Finally, it is also entirely predictable: '[w] hat the Grand Chamber was being asked to do in the context of this referral was to resolve legal uncertainty as a result of the development of diverging case-law on the just satisfaction question outlined above (whereby some chambers award just satisfaction against some States in the absence of a claim while others, in cases concerning other States, do not). ${ }^{206}$ Since the Grand Chamber has now ruled on this issue in order to clarify the Court's approach and has created a precedent for all future cases in which no claim for damages is made, it has finally removed the last element unpredictability - which could have potentially allowed previous decisions to have a deterrent impact. ${ }^{207}$

\section{Interstate case: Cyprus v Turkey}

The interstate case Cyprus v Turkey is the second case in which the Court is thought to have implicitly awarded punitive damages. The initial judgment, which was rendered in 2001, found fourteen violations in relation to the situation in the northern part of Cyprus (the military intervention by Turkey in July and August 1974). These included the violation of the right to property and family life in relation to the homes and immovable property of displaced Greek Cypriots; the violation of prohibition of degrading treatment in respect of living conditions of Greek Cypriots in the Karpas region of the northern part of Cyprus; and a violation of the right to life in relation to Greek Cypriot missing persons and their relatives. From 2001 to 2012 and despite countless interventions by the Committee of Ministers little was done to redress the violations or indeed to compensate the suffering of victims and their heirs. In 2012, the case returned to the Court for the determination of just satisfaction. In the end in 2014, the Grand Chamber awarded the Cypriot Government aggregate sums of 30 million EUR for nonpecuniary damage suffered by the surviving relatives of 1456 missing persons, and 60 million EUR for non-pecuniary damage suffered by the enclaved residents of the Karpas peninsula.

Judge Pinto in his concurring opinion labels these awards as punitive. The reasons for this are, Pinto argues, that the exact number of individual victims of human rights violations was not established, and in fact that the victims in the Karpas region were neither identified nor identifiable on the basis of the evidence in the file. The Court did not establish any criteria for the distribution of the compensation among the victims or their lawful heirs and did not provide any rules about devolution of compensation in cases where victims and their lawful heirs cannot be found. As Pinto puts it 'in this eventuality, the claimant State will be the final beneficiary of the amounts paid by the respondent State. The punitive nature of this compensation is flagrant. ${ }^{208}$ This statement might seem like a condemnation, but Pinto welcomes

punitive damages [as] an appropriate and necessary instrument for fulfilling the Court's mission to uphold human rights in Europe and ensuring the observance of the engagements

\footnotetext{
${ }^{204}$ Cyprus v Turkey (n 25), concurring opinion of Judge Pinto, para 13.

205 See Putintseva v. Russia app. no. 33498/ 04, (ECtHR 10 May 2012).

${ }^{206}$ Nagmetov v Russia (n 191), concurring opinion of Raimondi, O’Leary and Ranzoni, para 5.

${ }^{207}$ Though note the concurring opinion which underlines that the conditions 'are vague and imprecise'. Nagmetov

$v$ Russia (n 191), concurring opinion of Judge Nussberger and Lemmens, para 20.

${ }^{208}$ Cyprus v Turkey (n 25), concurring opinion of Judge Pinto, paras 12-13, emphasis added.
} 
undertaken by the Contracting Parties in the Convention and the Protocols ... This conclusion applies with even greater force in the case at hand, where the respondent State not only committed a multitude of gross human rights violations over a significant period of time in northern Cyprus, and did not investigate the most significant of these violations adequately and in a timely manner, but also deliberately failed year after year to comply with the Grand Chamber's judgment on the merits delivered a long time ago with regard to these specific violations. ${ }^{209}$

In comparison to Nagmetov, the award in Cyprus v Turkey is clearly unpredictable and the overall amount of the non-pecuniary compensation is high (due to the uncertain but high number of victims). However, as with Nagmetov, the majority opinion of the Court is at pains to underline that it in no way departs from previous case law. In this regard, the Court emphasizes that according to the very nature of the Convention, it is the individual, and not the State, who is directly or indirectly harmed and primarily 'injured' by a violation of one or several Convention rights. Therefore, if just satisfaction is afforded in an inter-State case, it should always be done for the benefit of individual victims. Citing the ICJ decision in Diallo, ${ }^{210}$ the Court finds that the sum awarded to the applicant State in the exercise of diplomatic protection of its citizens is intended to provide reparation for the latter's injury. Just satisfaction is awarded - the Court argues - to two sufficiently precise and objectively identifiable groups of people, that is, 1,456 missing persons and the enclaved Greek-Cypriot residents of the Karpas peninsula. The damages are not sought "with a view to compensating the State for a violation of its rights but for the benefit of individual victims. ${ }^{211}$ In this regard, the receiving State is under an obligation to "transfer to the injured person any compensation obtained for the injury from the responsible State...'. ${ }^{212}$

It is clear from these statements that the Court is trying to go no further than general international law allows. The damages - referred to again as compensation - are intended for the individual and not the State. Yet, the Court's insistence on 'compensation' may also be strategic. By insisting on the compensatory nature of the award, the Court is counting on the fact that 'it is often difficult to draw a line between damages designed to punish the wrongdoing state and purely compensatory damages taking into account the state's degree of misconduct. ${ }^{213}$ If compensatory nature of the damages is maintained, then perhaps the state is more likely to comply. In this respect, the Court is perhaps aware of studies which show that in contrast to controlled experiments on individuals, which speak in favour of retributive framing, in certain legal orders damages which are openly labelled as 'punitive' often go unenforced. Arbitral punitive damages for example are 'generally not enforceable in jurisdictions that do not recognize this remedy.' ${ }^{214}$ Castagno observes that in countries like Italy and Germany, 'the public policy defence ... could ... represent a strong bias against the enforcement of punitive damages awards' ${ }^{215}$ He takes same view for the UK, considering that under English law, such relief is not available in contract cases. ${ }^{216}$ Beyond arbitral awards, similar trends have been noted even in domestic legal orders, which allow for such damages

\footnotetext{
209 ibid., para 19.

${ }^{210}$ Case Concerning Ahmadou Sadio Diallo, Guinea v the Democratic Republic of Congo, Judgment on compensation, [2012] ICJ Rep 324, 19th June 2012.

${ }^{211}$ Cyprus v Turkey (n 25) main judgment, paras 45-47.

${ }^{212}$ Referring to the Articles on Diplomatic Protection, art 19.

${ }^{213}$ Nina Jorgensen, The Responsibility of States For International Crimes, (OUP, 2000), chapter 14.

${ }^{214}$ Markus A Petsche, 'Punitive Damages in International Commercial Arbitration: Much Ado about Nothing?' (2013) 29 Arbitration International 89, 101.

${ }^{215}$ Niccolo Pietro Castagno, 'International Commercial Arbitration and Punitive Damages', (2011) 4 Revista de Arbitraje Comercial y de Inversiones 729, 747; Nigel Blackaby, Constantine Partasides et al., Redfern and Hunter on International Arbitration (2009, Thomson Sweet \& Maxwell, 4th edition), 530-531.

216 Ibid.
} 
(like the US). Although in those jurisdictions the enforcement of punitive damages may not be an issue, the practice shows that the awards are often reduced on appeal. ${ }^{217}$

If - as Pinto argues - the Court is using damages 'to prevent further violations of human rights and punish wrongdoing governments', 218 then perhaps the Court believes that 'covertness' is a necessary element of achieving the aim pursued. In the context of international law, which relies heavily on states' willingness to comply voluntarily with judicial decisions, judgments have to persuade states to accept and enforce the ultimate award. If states perceive damages as openly retributive, they may treat them as inappropriate and excessive and may as a consequence withhold compliance. In proceedings before the Court, Turkey for example explicitly argued against the use of punitive damages, reminding the Court that the Convention does not guarantee a right to punitive damages and that the case law has consistently rejected them. ${ }^{219}$ It insisted that no money should be paid for the unidentified beneficiaries. Since the decision was rendered in 2014, Turkey has consistently avoided calls to provide any response to the decision or information regarding when the payment would take place. At each of its meetings since June 2015, the Committee of Ministers recalled that the obligation to pay the just satisfaction awarded by the Court is unconditional and called upon the Turkish authorities to pay the sums awarded in the judgment. Yet Turkey's silence continues even in the face of the expired time-limit (18 months), after which the default interest of 6\% started to run. Compliance with the just satisfaction decision seems less and less likely.

Yet, it is striking that since the 2014 decision was rendered, Turkey has in fact begun addressing the violations from the 2001 judgment. Within a few months of the 2014 decision, it started putting in place a domestic scheme for restitution, exchange or compensation for those deprived of property; it has also begun to provide access for experts to military zones, so that excavations of those missing can be started, as well as to archives to determine the location of remains, etc. ${ }^{220}$ The judgment therefore appears to have nudged the state to begin to address the underlying issues. In this regard, perhaps Pinto's decision to openly call the award 'punitive' (and/or the surprisingly high level of the award) may have helped nudge the state into action. It is possible that the 30 and 60 million payments will never be made, ${ }^{221}$ but the judgment was not without impact. If the aim of using punitive damages (implicitly or explicitly) is to trigger different behaviour from the state, then perhaps Cyprus $v$ Turkey is a good beginning.

\section{Conclusion}

In this article, I show how the choice of remedy affects compliance and why aggravated or punitive damages look like an ideal option to nudge states into compliance. I explore recent arguments by scholars and judges who argue that the European Court of Human Rights should actively shift its approach (or perhaps already has) to nudge state behaviour towards compliance and prevention of future violations. However, based on my empirical research, I show that the current case law presents several obstacles to the introduction of punitive damages. Building on the economic analysis of the law and insights from behavioural sciences, I show how the Court's approach fails to comply with any(!) of the elements needed to

\footnotetext{
${ }^{217}$ DG Owen 'A Punitive Damages Overview: Functions, Problems and Reform', (1994) 39 Villanova Law Review 363; in fact empirical studies show that punitive damages are not that much higher than compensatory damages, even when recognized as punitive.

${ }^{218}$ Cyprus $v$ Turkey (n 25), concurring opinion of Judge Pinto, para 13.

${ }^{219}$ Cyprus v Turkey (n 25) main judgment, para 55.

220 State communications to the Committee of Ministers: DH-DD(2017)1022 of 19/09/2017 and DHDD(2017)972 of 08/09/2017; DH-DD(2016)707).

${ }^{221}$ Especially given the default interest that applies if the state does not comply in 18 months.
} 
incentivize states to change their behaviour, specifically the high value of awards, predictability and retributive framing. If damages should seek to incentivize states to change their behaviour and thus serve the purpose of deterrence, it is quite clear from the practice of the Court, that judges on the bench have actively avoided using damages for this purpose. Only in one decision - Cyprus v Turkey - the awards are sufficiently high and unpredictable, as well as having been openly called out as punitive, to fulfil the criteria of punitive damages. It is this decision that offers some indication of the implications of a potential shift in the remedy structure. Although the Court appears to be clearly resistant to the idea of punishing states through money, Cyprus $v$ Turkey appears to suggest that unpredictable high value judgments may nudge states to begin to redress the underlying violation. Although in a system that relies on voluntary compliance such damages are unlikely to be paid out, they may nevertheless encourage states to conduct a cost-benefit analysis and conclude that it is best to get rid of structural/systemic problems than to continue the violation.

Cyprus v Turkey is of course an outlier and cannot persuasively and on its own reaffirm the idea of unpredictable, high value punitive damages; especially in light of such consistent case law to the contrary. Yet, the example shows that insights from behavioural economists could perhaps be applied even in state context and could be used to inform our thinking about the reform of the current remedy structure. Although states are not individuals and may not behave like individuals when it comes to money (eg when damages are called 'punitive', states are perhaps less likely to pay them), they may nevertheless react to a decision imposing such awards. And this reaction is often more than is triggered by existing monetary and nonmonetary remedies. 